\title{
Improving diets with wild and cultivated biodiversity from across the landscape
}

\author{
Bronwen Powell ${ }^{1} \cdot$ Shakuntala Haraksingh Thilsted $^{2}$ - Amy Ickowitz ${ }^{1}$. \\ Celine Termote $^{3} \cdot$ Terry Sunderland $^{1}$. Anna Herforth ${ }^{4}$
}

Received: 21 January 2015 / Accepted: 8 April 2015 /Published online: 13 May 2015

(C) The Author(s) 2015. This article is published with open access at Springerlink.com

\begin{abstract}
This paper examines the literature on how biodiversity contributes to improved and diversified diets in developing countries. We assess the current state of evidence on how wild and cultivated biodiversity in all forms is related to healthy diets and nutrition, and examine how economic factors, knowledge and social norms interact with availability of biodiversity to influence both production and consumption choices. The paper identifies areas where evidence is lacking and ways to build synergies between nutrition-sensitive approaches and efforts to ensure sustainability of food systems and the natural environment.
\end{abstract}

Keywords Agrobiodiversity · Wild food · Landscape · Fish · Nutrition $\cdot$ Dietary diversity

\section{Introduction}

There is growing commitment to nutrition-sensitive approaches in agriculture (Pinstrup-Andersen 2013a, b;

Special section series Strengthening the links between nutrition and health outcomes and agricultural research

Bronwen Powell

b.powell@cgiar.org

1 CIFOR, Jalan CIFOR, Situ Gede, Bogor 16000, Jawa Barat, Indonesia

2 WorldFish, House 22B, Road 7, BlockF, Banani, Dhaka 1213, Bangladesh

3 Bioversity International, Via dei Tre Denari, 472/a, 00057 Maccarese, Fiumicino, Italy

4 Independent Consultant, New York, USA
Ruel and Alderman 2013; Herforth and Dufour 2013). While much of the current research and dialogue acknowledges the importance of agriculture for nutrition, there is relatively little emphasis on the role of biodiversity in food and agricultural systems (Frison et al. 2011; Heywood 2013; Hunter and Fanzo 2013). The growing attention to the sustainability of diets and food systems highlights the need for greater attention to the role of biodiversity (Sunderland 2011; Macdiarmid et al. 2012; Burlingame and Dernini 2012; Macdiarmid 2013; Hunter and Fanzo 2013). Ensuring sustainability and resilience is arguably one of the most important roles that biodiversity plays within the food system (Johns and Sthapit 2004; Toledo and Burlingame 2006; Frison et al. 2011; Vinceti et al. 2013; Sunderland et al. 2013; Hunter and Fanzo 2013). In the same way that biodiversity supports ecosystem services, diversity within the food system is likely to be essential for resilience in the face of social, cultural, economic and environmental change (Frison et al. 2011; Johns and Sthapit 2004; Dufour et al. 2014). Moreover, there is increasing evidence that small changes in food environment (the context in which food is procured, prepared and consumed) can have significant impacts on dietary choice (Chadwick et al. 2013). In the context of developing countries, diversity within rural and agricultural landscapes may be an important part of a food environment that supports healthy dietary choices (Jones et al. 2012; Powell et al. 2013a). Biodiversity serves multiple functions within food and agricultural systems. This paper aims to examine one of those functions: whether and how biodiversity can improve diets and nutrition in developing countries.

Biodiversity exists within the food and agricultural system in many forms and at various scales. Diversity within the food system includes: cultivated species and on-farm diversity 
(crop diversity and agrobiodiversity ${ }^{1}$ ) (Harden et al. 2000; Brookfield 2002); and, wild species (which include those used as food directly or as well as wider biodiversity that supports ecosystem services). The dichotomization of wild vs. cultivated food species should be cautioned against; many (if not most) wild species actually fall along a continuum, from wild species under various degrees and types of human management and intervention through to domestication (Bharucha and Pretty 2010). Most landscapes include a diversity of land uses: landscapes including both agricultural and nonagricultural areas are often managed to ensure harvest of wild and cultivated species simultaneously (Anderson 2006; Padoch and Sunderland 2013). Diversity within the food system occurs across multiple scales: from genetic diversity within one species of crop or animal, to species diversity, to ecological diversity across the landscape.

For the main review sections of the paper, we conducted searches on Google scholar and Web of Science. ${ }^{2}$ Because the literature on this topic is scattered across diverse disciplines (including nutrition, nutritional ecology, anthropology, agriculture, fisheries and aquaculture and forestry) we also drew on our professional networks and collective knowledge to identify papers that were not identified using key word searches. Additionally, we identified key journals and other sources where we expected to find information not identified using other search methods and we reviewed the table of contents and abstracts from these going back to the 1970s (e.g. Human Ecology and Ecology of Food and Nutrition). Finally, we reviewed the reference lists of previous papers and reviews (e.g. Penafiel et al. 2011). We focused on primary research from low- and middle-income countries that examined relationships between various aspects of diversity within the agricultural system and landscape and measures of diet or nutrition.

The majority of studies identified in this review used measures of diet or dietary quality (including intake of key nutrients, dietary diversity and consumption of micronutrient-rich foods). Dietary diversity was one of the most common outcome measures used. Dietary diversity is defined as the number of either food items or food groups consumed by an individual or household in a given period and is proposed as an

\footnotetext{
${ }^{1}$ The Convention on Biological Diversity (CBD) defines agrobiodiversity as all living organisms and the ecosystem associated with agriculture and food production, while Bioversity International's definition includes only cultivated crops. Herein we use "crop diversity" to specify measures that include a count of the number of cultivated species on a farm (which in some studies includes just plants while in other studies livestock and aquaculture species), and agrobiodiversity to specify all species found on farm (both cultivated and wild) as per the CBD definition.

${ }^{2} \mathrm{~A}$ list of search terms used to identify papers is provided in each section below.
}

aspect of a healthy diet (Ruel 2003). Theoretically, greater dietary diversity increases the likelihood of consuming adequate amounts of all food components essential to health (Gibson et al. 2000; Wahlqvist 2005; Johns and Sthapit 2004). Evidence linking dietary diversity to energy and micronutrient adequacy, and to child growth is now well established (Ruel 2003; Arimond and Ruel 2004; Arimond et al. 2010; Kennedy et al. 2011). Most papers followed recent guidelines, which suggest the use of a Dietary Diversity Score (DDS) that includes between 6 and 14 food groups (FAO and FANTA 2007; Kennedy et al. 2011). Intake of under-consumed, nutritionally-important food groups such as fruits and vegetables (Hall et al. 2009; Boeing et al. 2012; WHO and FAO 2004; Siegel et al. 2014) and animal source foods (ASFs) (Murphy and Allen 2003) was also commonly used by studies identified in this review.

This paper starts with two review sections: the first looks at how agrobiodiversity and agricultural practices and interventions that enhance diversity within the food production system (including home gardens and aquaculture) contribute to diet quality and nutrition; the second section examines evidence for whether and how aspects of wild biodiversity (e.g. wild foods, trees, forests) contribute to diets and nutrition. These two sections are followed by an examination of the social, cultural and economic factors that influence dietary choices or management of rural landscapes. The conclusions highlight some of the gaps in knowledge and provide suggestions for what researchers and practitioners from diverse fields can do to draw on and contribute to this growing body of knowledge, as well as to support better integration of efforts to improve nutrition and food security and to conserve biodiversity.

\section{Agrobiodiversity for nutrition}

Agrobiodiversity is believed to contribute to human nutrition through many pathways, including increasing dietary diversity and quality, improving income, enhancing resilience and providing the genetic resources for future adaptation (including biofortification) (Toledo and Burlingame 2006; Frison et al. 2011; Berti and Jones 2013; Heywood 2013). Khoury et al. (2014) recently demonstrated increasing homogeneity in the global food supply, and Heywood's recent review (2013) laid out the ways historical simplification of global and local agricultural systems has likely decreased availability of diverse foods. Berti and Jones (2013) noted that while there are plausible mechanisms for biodiversity to contribute to improved nutrition, relationships are often assumed without supporting documentation.

To fill this gap, we reviewed the small but growing collection of studies that have investigated associations between crop diversity (or agrobiodiversity) and dietary diversity or nutrition outcomes. We conducted searches using key words 
"diet" or "nutrition" or "dietary diversity" and "agrobiodiversity" or "crop diversity" or "production diversity". On Web of Science, these search terms identified 30 articles, two of which met our criteria: we included only primary research papers that measured dietary intake, dietary diversity or nutritional status. Through the additional search strategies described above we were able to identify a total of 12 studies, which reported primary data that examine these relationships (Table 1 ).

Of the studies which measured dietary diversity at the household or individual level: six reported a positive association with crop diversity (Ekesa et al. 2008; Herforth 2010; Powell 2012; Jones et al. 2012, 2014; Oyarzun et al. 2013), one reported a positive association in one community but not another (Dewey 1981), and two reported no association (Torheim et al. 2004; Remans et al. 2011). Keding et al. (2012) showed an association between diversity of vegetables cultivated and dietary diversity (number of food groups). Two studies that looked at nutrient intake found a positive relationship between crop diversity and mean nutrient adequacy across multiple nutrients (Torheim et al. 2004; Powell 2012). One study showed an association between crop diversity and positive infant and young child feeding practices (Jones et al. 2012). Two further studies reported positive relationships between crop diversity and intake of nutritious foods such as fruits and vegetables (Herforth 2010; Jones et al. 2014). Remans et al. (2011) reported an association between crop diversity and dietary diversity at the village level, but not at the household level.

Of the 12 studies included in Table 1, three included research sites in Latin America and eight were conducted in Africa, while one looked at global data. Many of the studies on this topic have used small samples sizes and simple analyses to show correlations (often without controlling for confounding factors). The study by Oyarzun et al. (2013) was the first study, to our knowledge, to use field-based assessment of agrobiodiversity. Jones et al. (2014) made a significant contribution by using a large nationally-representative sample and a sophisticated analytical approach. Remans et al. (2014) examined how production diversity relates to the diversity of food available at a national level, adding a new scale of analysis to the current body of knowledge.

Despite limitations, and a possible bias for publication of positive results, the consistency of a relationship between dietary outcomes and crop diversity across existing studies is notable. More information is needed to understand the reasons for these associations as well as the impact of different study methodologies; seasonality and agroecology on relationships. There is a clear need for additional work in understudied regions, notably Asia, Latin America and the Caribbean, as well as for an improved understanding of how factors - such as market access, farm size, and wealth - interact with and mediate the relationship between agrobiodiversity and diet and nutrition.
Thus far we have examined relationships between crop or species diversity and diets or nutrition. However, the majority of agriculture-nutrition interventions that have focused on diversifying food production and improving diets have done so through home gardens, aquaculture, and small livestock production. The evidence for how home gardens, fisheries and aquaculture contribute to diet quality and nutrition are summarized in the next two sections. Livestock and animal production have been covered elsewhere (e.g. Leroy and Frongillo 2007; Randolph et al. 2007).

\section{Home gardens}

Home gardens are often one of the most diverse parts of the farm and agricultural system, sometimes containing more than 200 useful species (Eyzaguirre and Linares 2010). A study in Bangladesh found that the type and diversity of the home garden determined maternal vitamin A intake but that size of the garden did not (Bloem et al. 1996).

Four separate reviews of the impacts of agricultural interventions on nutrition outcomes have concluded that interventions involving home gardens are the type of agriculturenutrition intervention that are the most often rigorously evaluated, with evidence of improved diets (Tontisirin et al. 2002; Berti et al. 2004; Girard et al. 2012; Masset et al. 2012). Several of the studies reviewed showed that home gardens increased access to and intake of fruits and vegetables and/or vitamin A (Berti et al. 2004; Masset et al. 2012). Faber et al. (2002) found that a gardening intervention in South Africa increased consumption of vitamin A rich foods and increased serum retinol concentrations in children in intervention communities, compared to control communities where serum retinol decreased.

The reviews all conclude that the majority of home garden interventions are able to increase consumption of fruits and vegetables, although few have demonstrated an impact on biochemical or anthropometric measures of nutritional status. The absence of effect on nutritional status outcomes is likely largely due to inadequate sample size and other issues with study design (Masset et al. 2012; Ruel and Alderman 2013). Dietary outcomes are probably the more appropriate outcome in which to expect to see an impact (ISPC 2014). Some studies suggest that, in some cases, a lack of effect is due to the fact that garden produce may replace other nutritious foods in the diet (Bushamuka et al. 2005) or that the degree of women's control of income earned can also impact success (Brun et al. 1989).

\section{Capture fisheries and aquaculture}

In many poor populations in developing countries, fish is the most frequently consumed ASF, increasing diversity of diets, which are dominated by starchy staple foods (Belton and 

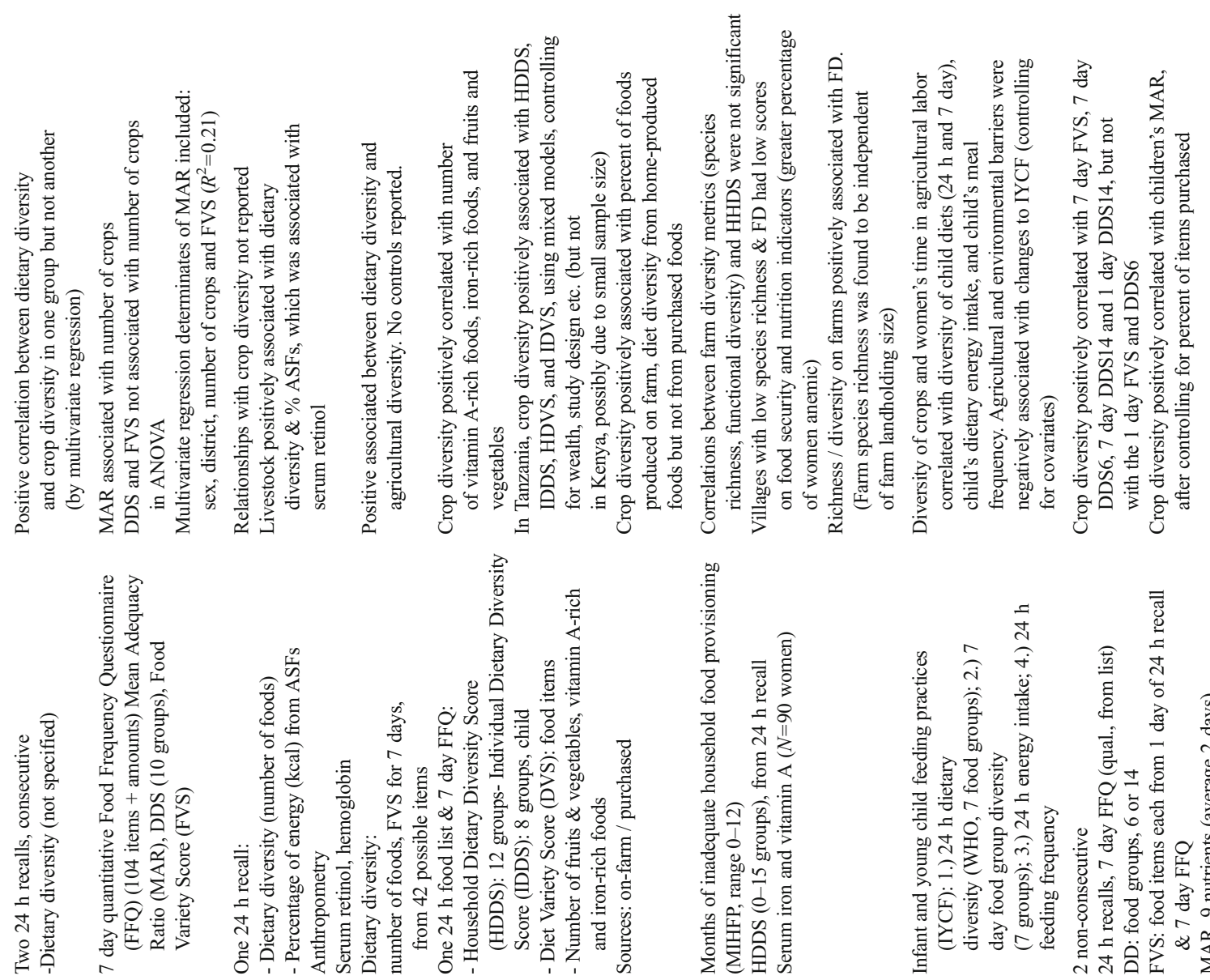

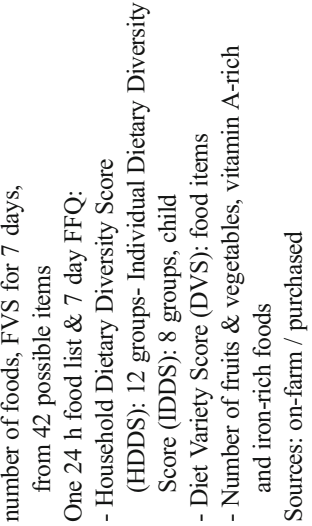

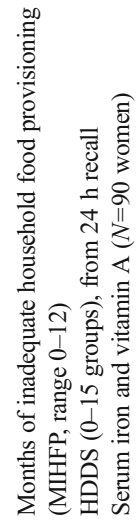

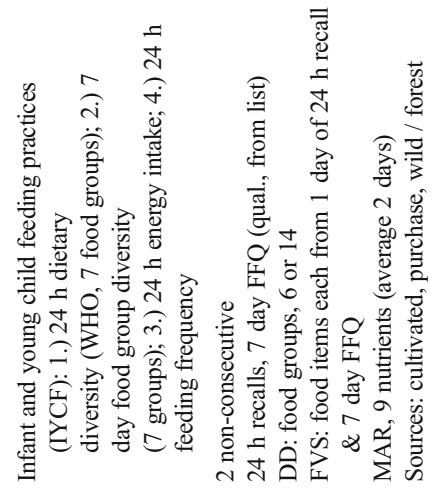

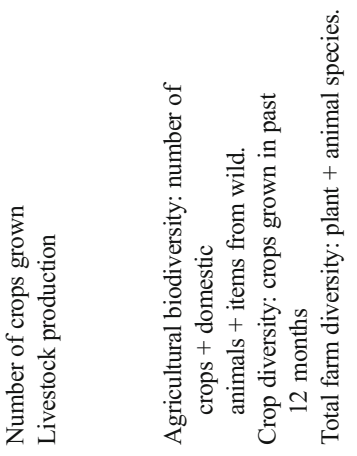

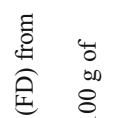

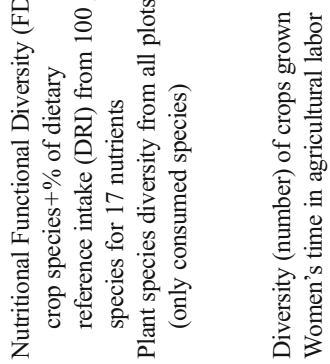

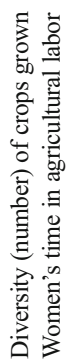
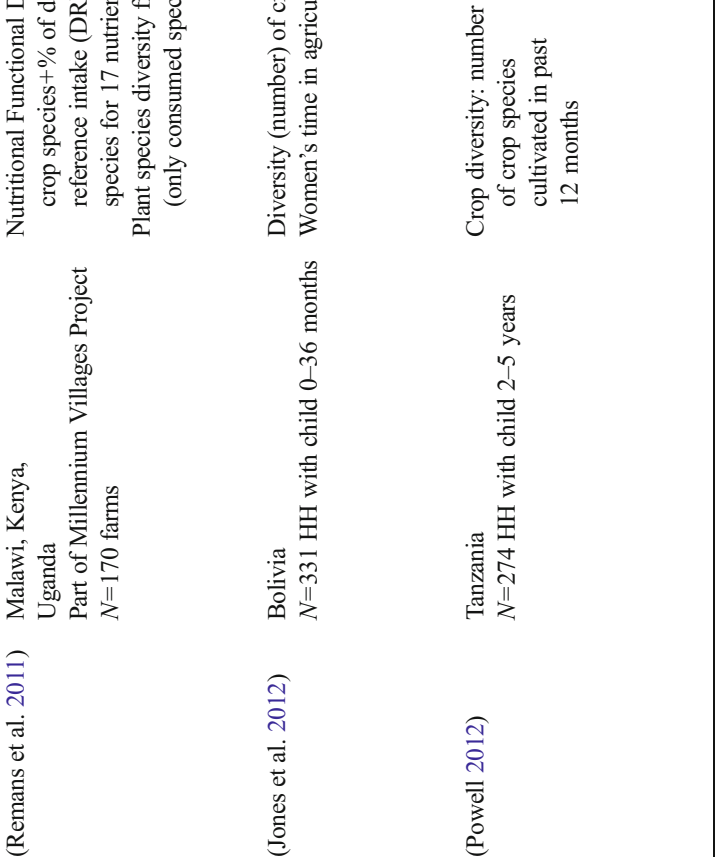


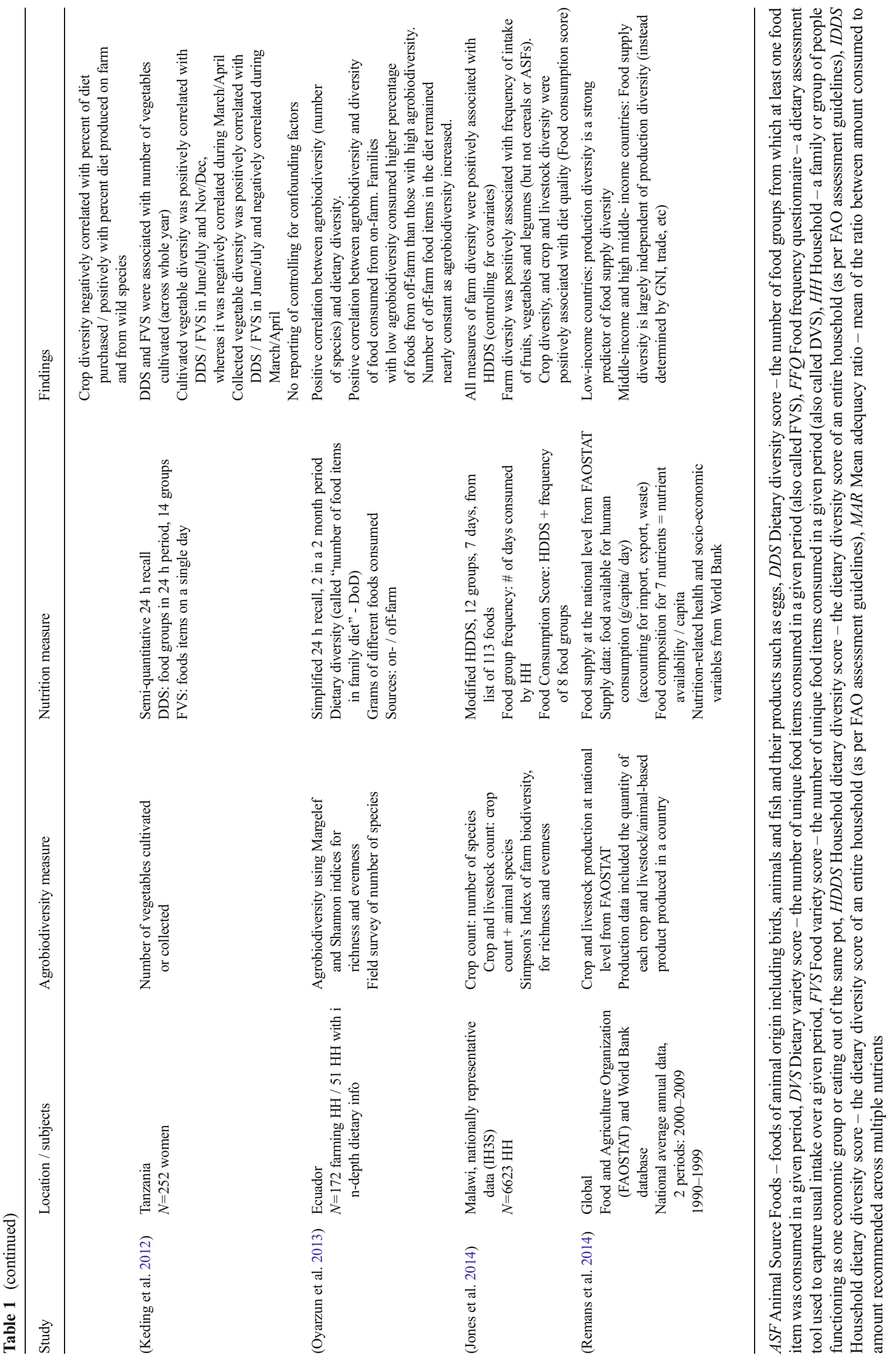


Thilsted 2014). In Malawi, Kenya, and Tanzania, rural populations living close to lakes rely on small wild fish as the major ASF (Haug et al. 2010). In parts of Latin America (Dufour 1992; daSilva and Begossi 2009) and Laos (Powell et al. 2010), wild fish provided the large majority of ASFs in the diet. Halwart (2006) reported that in rice-based aquatic agricultural systems, wild biodiversity was an important source of wild foods such as crustaceans and insects, in addition to fish.

In rural Bangladesh fish is the third most commonly consumed food (after rice and vegetables). The diversity of fish species consumed is also high, up to 75 species. In the 1990s the majority of species consumed were wild ( $\sim 50 \%$ smallsized) (Thilsted 2013). Small fish species from the wild, as they are eaten whole (with head, bones and viscera) are particularly rich in minerals and vitamins, in addition to animal protein and essential fats (Thilsted et al. 2013). In recent years, there has been rapid growth in inland aquaculture and an associated increase in the consumption of a few large-sized farmed fish species. Concomitantly, pressures on inland and marine fisheries have led to a decreased intake of wild fish and reduced diversity of species consumed (Belton et al. 2014). In Bangladesh, initiatives such as community-based fisheries management and re-establishment of micronutrient-rich small indigenous fish species in some water bodies have led to a many-fold increase in fish production and diversity, as well as increasing the proportion of consumed fish coming from small fish species (Thilsted et al. 2012). Homestead pond polyculture of carp and small fish species has led to increased fish production and household income as well as to improved nutritional quality of the total fish production: the large carp are sold, while the small fish are consumed in the household. In some areas, ponds are connected to rice fields which are inundated in the wet season, leading to a more than two-fold increase in fish production, as well as increased diversity of fish species (Thilsted et al. 2013).

As aquaculture continues to expand in many low-income countries, the changed production patterns towards production of very few, large fish species will lead to a reduction in fish species diversity for consumption, and may have negative consequences on diet quality (Belton and Thilsted 2014).

\section{Wild foods}

Contrary to what is often assumed, a significant proportion of wild foods come from agricultural areas or from around the home. In an agricultural community in Tanzania, $62 \%$ of wild foods were obtained from farm land, compared to $12 \%$ obtained from the forest (Powell et al. 2011), and in Thailand $35 \%$ of all wild foods came from paddies or fields, $23 \%$ came from forest or wooded areas, $14 \%$ came from within the village, and $12 \%$ came from rivers, ponds or swamps (calculated from Price 1997). The management of wild food species can range from completely unmanaged to almost domesticated or escaped species which are cultivated under some circumstances and wild in others (Anderson 2006; Bharucha and Pretty 2010; Turner et al. 2011). Many communities manage their farms, forests and landscapes to ensure production of wild foods (Anderson 2006; Turner et al. 2011; Bharucha and Pretty 2010; Padoch and Sunderland 2013).

The source, type and relative importance of wild foods varies greatly from one socio-ecological setting to another. For example, the nutritional importance of wild foods in sago-dependent forest communities of Indonesia (Ellen 2006; Dounias et al. 2007; Sasaoka et al. 2014) is likely very different from that for Mediterranean communities who value wild foods as part of their traditional culinary heritage (Pieroni et al. 2005; Pardo-De-Santayana et al. 2005; Batal and Hunter 2007; Hadjichambis et al. 2008; Powell et al. 2014). Although reviews have often portrayed wild foods as ubiquitous and habitually used by rural populations around the world (Scoones and Bishop 1994; Grivetti and Ogle 2000; Bharucha and Pretty 2010; Penafiel et al. 2011), their actual contribution to nutrition is dependent not only on availability but also on the number of people using them, frequency of use, and quantities consumed relative to other foods. Bharucha and Pretty (2010) used data from 22 countries in Asia and Africa and estimated that an average of 90-100 wild plant food species are used or available per location, but there have not been any reviews that expressly examine the actual contribution of wild foods to dietary intake and nutrition, relative to other foods in the diet.

Using key words "diet" or "nutrition" and "wild food" or "bush meat" or "forest food" on Web of Science we identified 99 articles. The majority of the articles were about the nutrition of non-human species, and only 5 papers met our criteria: we included only primary research papers that assessed the contribution of wild foods to diets or nutrition, relative to intake of foods from other sources (in terms of either amount or frequency). After additional search strategies described above, we identified 24 studies from low- or middle-income countries (Table 2).

Comparing findings from the different studies was complicated. Some studies examined "wild foods", while others looked at "forest foods" (although almost all "forest foods" are wild, many wild foods are not obtained from the forest). The studies also looked at different types of foods (one food group, plant or animal foods alone, or both plant and animal foods), in different populations and used different tools and time frames.

Of the 24 papers summarized in Table 2, 13 included information on all types of foods, two provided only information on meat, two on fish and meat, three looked exclusively at vegetables, two at fruit and, two others at wild plant foods. Geographically, 13 of the studies were conducted in Africa, four in Asia, and seven in Latin America. 


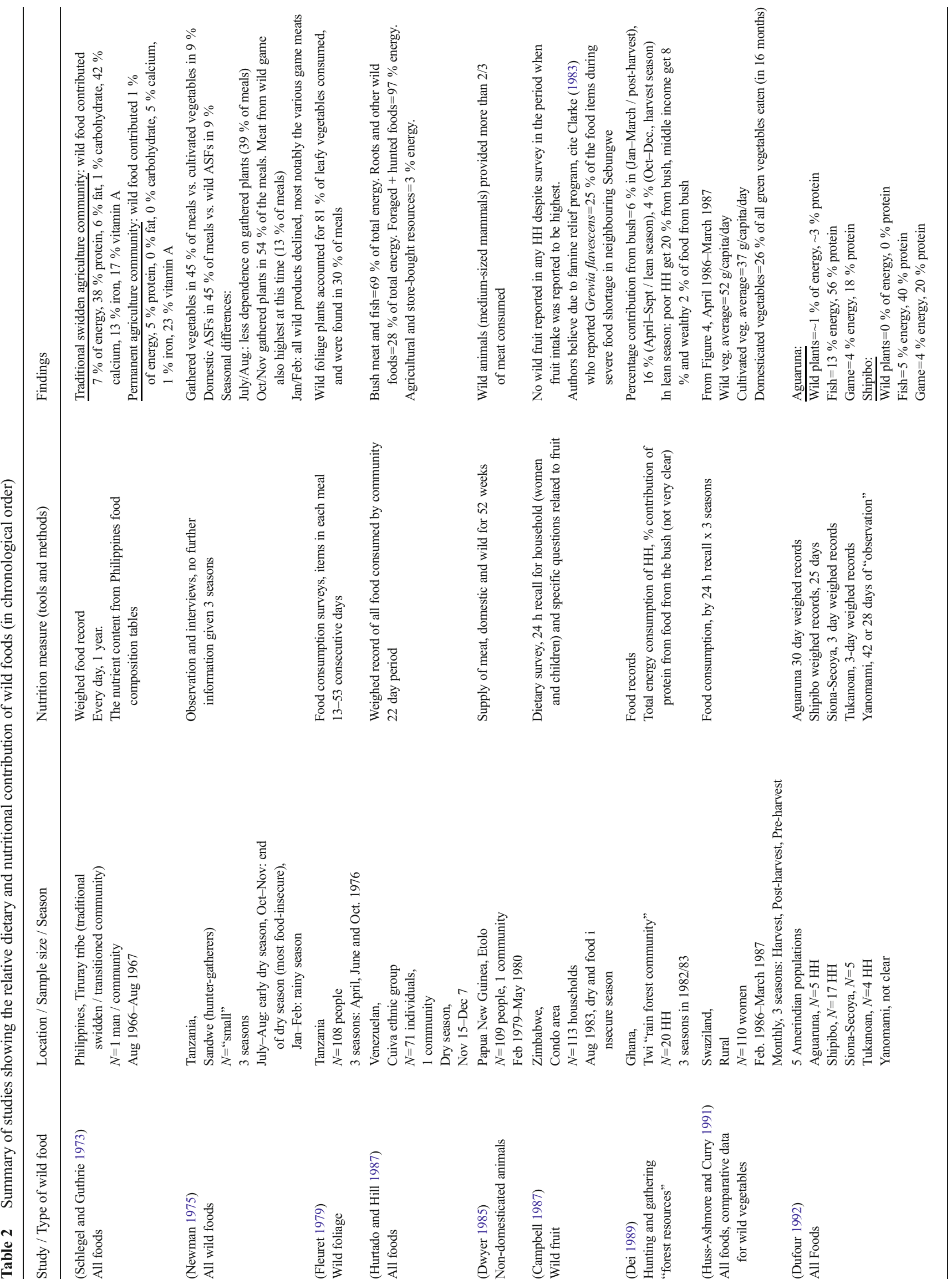




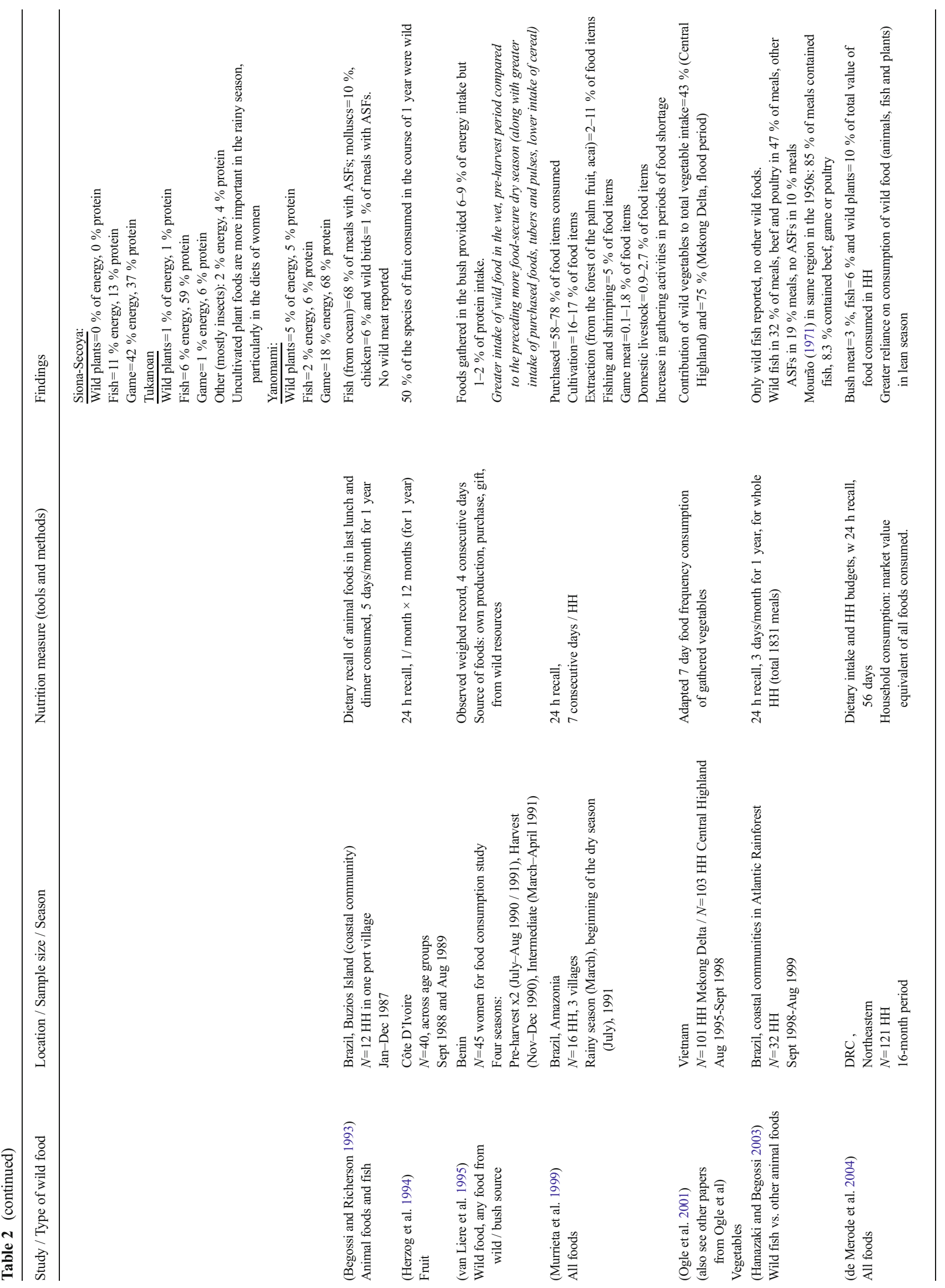




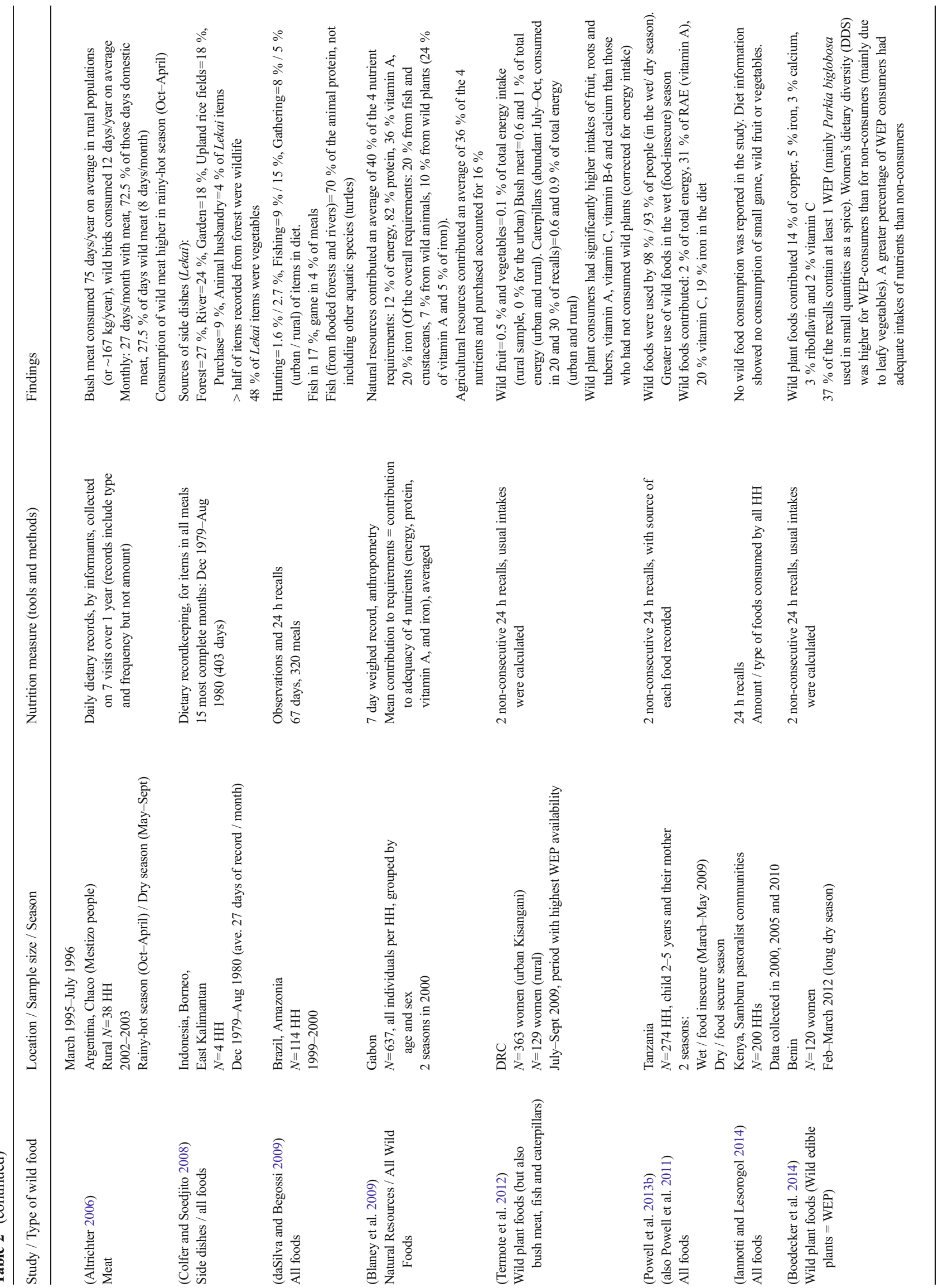


In a number of the studies, wild foods made up a significant portion of the diet, especially for non-staple food items (Hurtado and Hill 1987; Colfer and Soedjito 2008). The contribution that wild foods made to total energy intake was reported to be low in most studies (Schlegel and Guthrie 1973; van Liere et al. 1995; Termote et al. 2012; Powell et al. 2013b). Despite low or modest contributions to energy, wild foods accounted for a large portion of micronutrients consumed at a number of sites. In Gabon, Blaney et al. (2009) reported $36 \%$ of total vitamin A and $20 \%$ of iron in the diet came from "natural resources" (wild foods); in Tanzania, Powell et al. (2013b), reported $31 \%$ of RAE (vitamin A) and $19 \%$ of iron in the diet from wild foods; and, in a traditional swidden agricultural community in the Philippines, wild foods contributed $42 \%$ of calcium, $32 \%$ of riboflavin, $17 \%$ of vitamin A and $13 \%$ of iron (Schlegel and Guthrie 1973).

In some contexts wild vegetables appeared in a large portion of meals and made up the majority of all the vegetables consumed (Newman 1975; Fleuret 1979; Huss-Ashmore and Curry 1991; Ogle et al. 2001). For example in Vietnam, Ogle et al. (2001) reported that wild vegetables contributed $43 \%$ (Central Highland) and $75 \%$ (Mekong Delta, flood period) of the total weight of vegetables consumed. In Cote D'Ivoire, $50 \%$ of the species of fruit consumed in the course of 1 year were wild (Herzog et al. 1994), however a study in Zambia found no consumption of wild fruit in a period of food shortage (Campbell 1987).

In addition to protein, ASFs have a high density of bioavailable micronutrients and are thus often the primary source of some of the most important vitamins and minerals (Murphy and Allen 2003). Moreover, consumption of ASFs also enhance the absorption of micronutrients from plant foods in the same meal (Gibson et al. 2006). Nasi et al. (2011) estimated that bush meat accounts for up to $80 \%$ of the protein consumed by local communities in the Congo Basin (not in Table 1 due to methodological differences). Of the papers in Table 2, bushmeat contributed $0.1-2.7 \%$ of items, between 0.6 and $69 \%$ of energy and 6-68\% of protein in the diet (Hurtado and Hill 1987; Dufour 1992; Murrieta et al. 1999; Altrichter 2006; daSilva and Begossi 2009; Blaney et al. 2009; Termote et al. 2012). Insects are another nutritionally important food (FAO 2013), but few studies report their consumption relative to other foods (Dufour 1992). A study in DRC found caterpillars in $20-30 \%$ of recalls but they only contributed 0.6 and $0.9 \%$ of total energy intake (for urban and rural adult women respectively) (Termote et al. 2012).

In some contexts, consumption of wild foods (especially wild plant foods) appears to be quite limited (Termote et al. 2012; Campbell 1987) - one study reported a complete lack of wild foods in the study population's diet (Samburu in Kenya) (Iannotti and Lesorogol 2014). In studies from the Amazon, wild plant foods (aside from acai), especially vegetables, were scarce (Hurtado and Hill 1987; Dufour 1992; Murrieta et al. 1999; daSilva and Begossi 2009). A review by Katz et al. (2012) of work with multiple groups of Amerindians confirms that many ethnic groups consumed very little or no leafy vegetables. These findings highlight that caution is needed when interpreting the extent of wild food use from local people's reports of wild food availability within the community (Termote et al. 2012). In Benin, Boedecker et al. (2014) reported that of the 61 wild plant foods known by communities, only eight were reported as consumed. Similarly in Brazil, do Nascimento et al. (2013) found only very few cases of actual consumption (using a recall for the past week conducted in 2 seasons, $N=44$ ) in communities where local people listed 169 wild food plants as "used".

One of the limitations to studies seeking to quantify the contribution of wild foods to nutrient intake, is the lack of data on the nutrient composition for wild foods (Burlingame et al. 2009). Moreover, the data that do exist for underutilized crops, wild and traditional foods, are not always of a high standard (McBurney et al. 2004). On-going work to document the nutrient composition of wild foods indicates that some wild species have significant potential to increase the nutrient content of monotonous diets (Stadlmayr et al. 2013; Penafiel et al. 2011). In addition to nutrients, bioactive phytochemicals in wild plants may also have health benefits. Johns et al. (1999) demonstrated that wild leafy green vegetables had anti-cholesterolemic activity when consumed by East African pastoral communities.

There is a need for additional multi-disciplinary studies on wild foods. Such studies should: 1.Use rigorous botanical/ scientific methods to determine the identity of the wild foods consumed; 2 . Use proper dietary intake methodology to assess usual intake of foods and nutrients over multiple days (so as to estimate diet quality); 3. Contribute to knowledge of the nutrient and phytochemical composition of wild foods if possible; and 4. Include assessment of the diverse social, cultural and economic factors that may influence the use of wild foods and their contribution to nutrition.

\section{Forests and tree-based systems}

Rough estimates suggest that approximately $50 \%$ of the global fruit supply is from trees (in orchards or agroforestry systems) (Powell et al. 2013a). Home gardens can be a form of agroforestry (Kehlenbeck et al. 2007), and may be an important pathway through which agroforestry could contribute to nutrition (Jamnadass et al. 2013). A recent paper by Cerda et al. (2014) using yield and crop use information for cacao agroforestry systems in multiple Central American countries concluded that diversity in canopy trees is associated with increased fruit available for home consumption. However, to date, no published studies have tested the relationship between agroforestry (other than home-gardens) and dietary intake. 
Forests, especially tropical forests, are home to the majority of the world's biodiversity. In addition to the wild foods that they provide, forests and trees provide ecosystem services that support sustainable agricultural production (Pimentel et al. 1997; Millennium Ecosystem Assessment 2005; Arnold et al. 2011; Sunderland et al. 2013; Vinceti et al. 2013). One of the more recent lines of evidence for the possible importance of forests for nutrition comes from studies that have paired tree cover (by satellite image) with dietary information. A study by Ickowitz et al. (2014) used dietary data from the Demographic and Health Survey (DHS) in 21 African countries and showed a positive relationship between tree cover and children's dietary diversity (ten food group DDS, 1 day of recall). They also found that consumption of fruits and vegetables increased with tree cover up to a peak of $45 \%$ tree cover and then declined, but did not find a significant relationship between tree cover and ASF consumption. Ickowitz et al. (under review) using DHS data for frequency of consumption over 7 days from Indonesia, found that children in areas with more natural forests consume ASFs more frequently. In addition, they found a positive association between the amount of land around a community characterized by 'medium' density tree cover (20-50\%) and frequency of consumption of vitamin-A rich fruit, green leafy vegetables, ASF, and 'other' fruits and vegetables. Johnson et al. (2013) used DHS data from Malawi and found that children living in areas with more forest cover consumed more vitaminA-rich fruit, and that net forest loss was associated with less diverse diets. Using data for household level rather than village level forest cover in a study from Tanzania reported a relationship between multiple dietary diversity scores (1 and 7 day DDS and FVS) and tree cover within a 1.5 or $2 \mathrm{~km}$ radius of the home (Powell 2012).

Although existing studies consistently report relationships between dietary intake and tree cover, the pathways between tree cover and diet remain a "black box." Income is an unlikely pathway: although forests and forest products may contribute to income that can support food security (Pimentel et al. 1997; Angelsen et al. 2014), most communities that live close to forests are poorer than those who live further away from forests (Angelsen and Wunder 2003; Sunderlin et al. 2008). Other plausible pathways include: an indirect impact of tree cover on diets through the types of food production systems practised in more forested landscapes (such as swidden agriculture and agroforestry); or, a direct contribution via the consumption of forest or agroforest products (Ickowitz et al. 2014). Another possible pathway is that biodiversity and forests contribute to ecosystem services needed for the production of nutritionally important foods (Sunderland et al. 2013; Foli et al. 2014); tree cover may provide a micro-climate which favors production of fruit and vegetables and pollination services for fruit and vegetable production (Powell et al. 2013a). More research is needed to understand the links between forest and tree cover and nutrition.

\section{Seasonality and resilience}

One of the most compelling theoretical arguments for the importance of diversity within the food system is that it provides seasonal evenness: when there are many species in the system, the likelihood is increased that one species or another is "in season" at all times. Of the papers in Table 2, the majority $(\sim 2 /$ 3 rds) of those that included information on seasonal differences showed higher dependence on wild foods in the lean or food insecure season (Newman 1975; Dei 1989; van Liere et al. 1995; de Merode et al. 2004; Colfer and Soedjito 2008; Powell et al. 2013b), although others suggest that seasonal variation is more dependent on availability than need (Dwyer 1985; Huss-Ashmore and Curry 1991; Dufour 1992). While in many cases wild food availability happens to correspond with the hungry season, e.g. (Powell et al. 2013b), in Thailand Moreno-Black and Somnasang (2000) reported higher wild food usage in the dry/hungry season when wild foods were less available. Decisions around wild food use are shaped by multiple factors, including: need, social and cultural preferences and norms, knowledge, seasonal availability, and the trade-offs in time, effort and convenience. In Indonesia, Colfer and Soedjito (2008) propose that the increased use of forest food in the dry season was a result of people having more time for hunting and gathering activities while they waited for the period when the rice fields can be burnt for the next agricultural cycle. There is strong evidence for the role of agroforest tree diversity in filling the seasonal fruit gap (Jamnadass et al. 2013; Kehlenbeck et al. 2013). A study from Malawi, Mozambique and Zambia found that 26 $50 \%$ of rural households relied on indigenous fruits as a coping strategy during critical seasonal hunger periods (Akinnifesi et al. 2004).

Wild and tree foods appear to fill a 'safety-net' function, at least during short seasonal food shortages; however, there are very few studies that test the role of biodiversity and wild foods in mitigating the impact of shocks. In Niger, $83 \%$ of informants reported increased reliance on wild foods during drought (Humphry et al. 1993). Conversely, one study in Zambia found no consumption of wild fruit in a period of food shortage (Campbell 1987). These findings suggest that a diversity of foods available from forests and tree foods is important as a source of resilience in the food system.

\section{Social, cultural and economic mediators}

Dietary choices are shaped by a broad range of psychological and social-cultural factors, as well as by the food environment 
(Khare 1980; Fischler 1988; Kuhnlein and Receveur 1996; Glanz et al. 2005; Story et al. 2008; Etkin 2009; Swinburn et al. 2013; Sobal et al. 2014). Similarly, production choices are shaped by economic, cultural, and ecological factors in addition to needs and preferences (Herforth and Harris 2014). There is increasing consensus that dietary choices are often driven by habit, subtle cues and differences within the food environment, and less by knowledge and conscious choice (Wansink 2007; Marteau et al. 2012; Chadwick et al. 2013; Hawkes 2013). Herforth and Ahmed (2015) describe the food environment in markets. Herein, we have considered agricultural and natural parts of the food environment. One characteristic of the food environment that influences dietary choices is convenience; for people in rural areas, biodiversity and wild foods may provide convenient access to nutritious foods which cost less in both time and money than purchased food from a market. In areas where market access is difficult or where markets do not function well, economic factors and market food environments may not be the strongest determinants of food choice: in these settings, we need to understand how the landscape (or natural food environment) affects diets. Results from some of the studies reviewed herein show associations between biodiversity and diet at the community or national level (e.g. Remans et al. (2014) - farm diversity, and Powell et al. (2011) —wild foods), suggesting that ensuring food supply diversity may support healthy dietary choices at the population level.

\section{The cost of food baskets with wild and traditional crops}

Recent studies have used linear programming to examine if it is theoretically feasible to meet energy and nutrient requirements using locally available foods and which food combinations do this most cost efficiently. Parlesak et al. (2014) showed that the addition of locally produced nutrient-dense foods to a food basket of 58 local standard foods, could reduce the cost by $61 \%$ and achieve recommendations for all micronutrients. A recent study in eastern Baringo District, Kenya investigated the role of wild food biodiversity in reducing the cost of a nutritionally adequate diet for women and young children using linear programming. Five wild edible plant foods where selected and entered into a model aiming to minimize cost and maximize nutrient adequacy of 12 nutrients using linear programming. Adding wild foods three or four times a week in the modeled diets, resulted in lower cost of meeting recommended iron intakes in all seasons (up to $64 \%$ ) (Termote et al. 2014).

\section{Economic influences on agrobiodiversity}

Enhanced income may be a mechanism through which agrobiodiversity contributes to diet quality, through the sale of crops and the purchase of nutritionally important foods, particularly if agrobiodiversity contributes to women's income (Herforth 2010). Of the studies reported in Table 1, four examined whether income was a mechanism through which crop diversity was associated with dietary diversity. The results of studies led by Oyarzun et al. (2013), Herforth (2010) and Powell (2012) all suggest that the relationship is driven by direct contribution to dietary diversity through home consumption rather than through an effect of income. Jones et al. (2014) report that those households dedicating a greater portion of land to cash crop production had greater dietary diversity, they note " $(t)$ he potential to earn income from a new crop may in fact motivate production diversification which could have spin-off benefits for diet diversity" p.9, (Jones et al. 2014). A paper by Johns et al. (2013) has recently reviewed the economic importance provided by agrobiodiversity in the form of traditional food species that remain part of evolving, diverse, biocultural systems, and have gained market value. These findings highlight that economic forces can, under the right circumstances, provide incentive to maintain or increase agrobiodiversity.

\section{Socio-cultural influences on wild food and agrobiodiversity management}

Many "traditional" and culturally important foods are wild or under-utilized crops (Kuhnlein 2009). Many of what Garibaldi describes as "cultural key-stone species" (species that play a pivotal role in the cuisine and food culture of a society), are wild foods or under-utilized crops (Garibaldi and Turner 2004). Conversely, in some cases social and cultural preferences deter the consumption of nutritious traditional foods, or the cultural importance of foods has been lost (Chweya and Eyzaguirre 1999). While this poses a barrier to interventions, social-marketing strategies have been very successful in the re-introduction of traditional vegetables in Kenya (Shiundu and Oniang'o 2007; Ngugi et al. 2007; Qaim et al. 2014) and in Lebanon (Batal et al. 2012).

Social and cultural factors affect decisions around how to manage food production systems and landscapes. In Ethiopia, the maintenance of a high diversity of enset varieties was reported to be a marker of social status (Harden-Baars 2000). In Peru, Coomes and Ban (2004) found that social networks and interactions were essential to the maintenance of agrobiodiversity in home gardens through the access to and exchange of seed and planting material. Similarly McGuire (2008) has described the importance of social networks for access to seeds and planting material. Finally, traditional knowledge is necessary to maintain diversity in complex, socio-ecological agricultural systems (Altieri et al. 2012), as well as for continued learning and experimentation needed to gain new adaptive varieties. Traditional values and preferences may help to maintain and foster the links between diet, 
nutrition, biodiversity and sustainability (Johns and Sthapit 2004; Kuhnlein 2009). In Mexico, women who had left their homes in the Yucatan to find wage labor in neighboring areas of Mexico, made special trips home to gather seeds and cuttings which they transported to their new home in order to enhance the diversity and make up of their new home gardens. The species contained in their home gardens form part of their culinary heritage and cultural identity (Greenberg 2003).

\section{Sustainability of wild food use and landscape management}

There are sustainability issues around wild food use, especially for bush meat (Nasi et al. 2011). While the populations of many species decline under even moderate hunting pressure, some smaller species have been found to be more resilient (Nielsen 2006; Arnold 2008; Nasi et al. 2008; van Vliet et al. 2010). Work on sustainability of harvest of non-timber forest products suggests that plant species which are not harvested for their roots or bark (such as wild fruit and vegetables) may be able to sustain heavier levels of harvest (Ticktin 2004).

Responses to scarcity of wild foods are shaped by knowledge and cultural practices. Belcher et al. (2005) suggest that commercialization and heavy harvesting of nontimber forest products can often lead to domestication. Johnson and Grivetti (2002) provide a case study of responses to decreasing availability of wild vegetables in Thailand, where they found that women collected and transplanted many wild species into their fields and gardens. Culturally bound food taboos and rules around where, when and what to hunt, have been suggested to support sustainable use of bush-meat (Ross et al. 1978; Wadley and Colfer 2004Colding and Folke 2001).

Many communities manage their landscapes (farms, gardens, fallows, pastures, ponds, rivers and forests) in ways that support both agricultural production and access to wild foods (Padoch and Sunderland 2013). The cultural importance of all aspects of food systems can be built on to support sustainable management that will simultaneously support biodiversity conservation and nutrition (Johns and Sthapit 2004).

\section{Discussion and conclusions}

In our review of studies seeking to link agrobiodiversity or crop diversity and nutrition, we identified 12 papers that included nutritionally relevant information. Six out of the eight studies which reported a relationship between crop diversity and some measure of individual or household dietary diversity reported a positive relationship. Both studies that looked at nutrient adequacy (MAR) reported a positive relationship, as did both studies looking at intake of nutritious foods.
Our review of the contributions of wild foods to the diet shows that in some communities, the consumption of wild foods is quite limited or absent, and in others, the majority of vegetables or ASFs come from the wild. Of the 24 papers reporting wild food use, ten (42\%) included only information on the frequency of consumption relative to other food items. Knowledge about the contribution to nutrition can be improved by information about amounts consumed at the individual level; of the studies in Table 2, only 14 included quantitative dietary assessment using individual weighed records or $24 \mathrm{~h}$ recalls.

This review has highlighted many gaps in current knowledge. Key future research questions include:

- How does agrobiodiversity or wild biodiversity contribute to overall diet quality (not just frequency of a given food group or intake of a few nutrients, to address all forms of malnutrition, including obesity and chronic nutrition related diseases)?

- Why studies have consistently identified a relationship between tree cover and diet; in which contexts does the relationship exist and what are the pathways?

- Is there a relationship between agroforestry and diets and nutrition? What are the relative impacts of presence / absence of agroforestry vs. the diversity of home gardens and agrobiodiversity?

- How does the scale of study (individual, household, community, country) affect results?

- In which socio-ecological settings and contexts do the relationships between biodiversity and nutrition persist and which factors mediate the relationship (e.g. especially market access, farm size, and wealth)?

- How do local communities manage their landscapes for healthy food production and which aspects of the rural food environment (landscape) support healthy dietary choices, in particular for combating the nutrition transition and diet-related disease?

These research questions are complex: addressing them will require innovative and interdisciplinary approaches and methodologies. Randomized control trials may not be appropriate for these sorts of research questions, given the complexity of socio-cultural-ecological systems and the near impossibility of randomizing forests, landscapes and biodiversity. Appropriate metrics that are easy to use and internationally accepted will help researchers from diverse fields to include diet and nutrition information in their studies.

Understanding complex and dynamic biocultural food systems and landscapes in a way that allows for better elucidation of connections between biodiversity and nutrition will require interdisciplinary and systems thinking. It will require that nutritionists think about landscapes and biodiversity, that foresters think about food as more than just calories, and that 
fisheries experts and agronomists think about traditional systems, decision making and how their decisions impact both biodiversity and nutrition. Fortunately, the global community of researchers and practitioners is increasingly receptive to this challenge. Food security and nutrition experts are increasingly applying multidisciplinary and systems level approaches to the understanding of the food system in its entirety (Hoffmann 2003; Kuhnlein 2009; Pinstrup-Andersen 2010). Food systems approaches consider the foods consumed; the places, technologies and resources needed to cultivate, harvest, produce and process them; as well as the knowledge and cultural practices for production, harvesting, processing, cooking and consumption (Kuhnlein 2009; Pinstrup-Andersen 2010).

Similarly, in conservation there has been a move toward landscape approaches in an effort to integrate conservation, agriculture, development and other competing land uses and land management (Sayer et al. 2013). Greater recognition of the importance of a wide range of ecosystem services for human health, nutrition and well-being has led to a further embracing of such integrated approaches.

The relationship between biodiversity and nutrition that seems to be evident from this review, suggests that we need to pay close attention to the potential of integrated approaches and to the resulting research findings. In addition to the need for further research, we must also seek to understand what the implications are for policy and what the messages to policy makers should be. Primarily, it suggests there is a need for more systems and multi-sectorial approaches to address the contemporary concurrent challenges of sustainable food systems that include forestry, conservation, agriculture, food security and nutrition.

Acknowledgments The authors gratefully acknowledge funding sources that allowed them to write this paper. T.S. and A.I. were supported by the CGIAR Research Program on Forests, Trees and Agroforestry (FTA), as well as funding from DfID and USAID. S.H.T. was supported by the CGIAR Research Program on Aquatic Agricultural Systems (AAS). C.T. was supported by the CGIAR Research Program on Agriculture for Nutrition and Health (A4NH). The views expressed are those of the authors and do not necessarily represent those of Bioversity International, CIFOR or WorldFish.

Open Access This article is distributed under the terms of the Creative Commons Attribution 4.0 International License (http:// creativecommons.org/licenses/by/4.0/), which permits unrestricted use, distribution, and reproduction in any medium, provided you give appropriate credit to the original author(s) and the source, provide a link to the Creative Commons license, and indicate if changes were made.

\section{References}

Akinnifesi, F. K., Kwesiga, F. R., Mhango, J., Mkonda, A., Chilanga, T., \& Swai, R. (2004). Domesticating priority miombo indigenous fruit trees as a promising livelihood option for smallholder farmers in southern Africa. Acta Hort (ISHS), 632, 15-30.

Altieri, M., Funes-Monzote, F., \& Petersen, P. (2012). Agroecologically efficient agricultural systems for smallholder farmers: contributions to food sovereignty. Agronomy for Sustainable Development, 32(1), 1-13. doi:10.1007/s13593-011-0065-6.

Altrichter, M. (2006). Wildlife in the life of local people of the semi-arid Argentine Chaco. Biodiversity \& Conservation, 15(8), 2719-2736. doi:10.1007/s10531-005-0307-5.

Anderson, K. (2006). Tending the wild: Native American knowledge and the management of California's natural resources. Berkeley: University of California Press.

Angelsen, A., \& Wunder, S. (2003). Exploring the forest-poverty link: Key concepts, issues and research implications. CIFOR Occasional Paper No. 40. Bogor: Centre for International Forestry Research.

Angelsen, A., Jagger, P., Babigumira, R., Belcher, B., Hogarth, N. J., Bauch, S., et al. (2014). Environmental income and rural livelihoods: a global-comparative analysis. World Development, 64(Suppl 1), S12-S28. doi:10.1016/j.worlddev.2014.03.006.

Arimond, M., \& Ruel, M. T. (2004). Dietary diversity is associated with child nutritional status: evidence from 11 demographic and health surveys. Journal of Nutrition, 134(10), 2579-2585.

Arimond, M., Wiesmann, D., Becquey, E., Carriquiry, A., Daniels, M. C., Deitchler, M., et al. (2010). Simple food group diversity indicators predict micronutrient adequacy of women's diets in 5 diverse, resource-poor settings. The Journal of Nutrition, 140(11), 2059S2069S. doi:10.3945/jn.110.123414.

Arnold, J. E. M. (2008). Managing ecosystems to enhance the food security of the rural poor: A situation analysis. Gand: IUCN, International Union for Conservation of Nature.

Arnold, J. E. M., Powell, B., Shanley, P., \& Sunderland, T. C. H. (2011). Forests, biodiversity and food security. International Forestry Review, 13(3), online.

Batal, M., \& Hunter, E. (2007). Traditional Lebanese recipes based on wild plants: an answer to diet simplification? Food \& Nutrition Bulletin, 28(Supplement 2), 303S-311S.

Batal, M., Al-Hakimi, A., \& Pelat, F. (2012). Dietary Diversity in Lebanon and Yemen: A tale of two countries. In D. F. Charron (Ed.), Ecohealth Research in Practice (Vol. 1, pp. 69-80, Insight and Innovation in International Development). New York: Springer.

Begossi, A., \& Richerson, P. J. (1993). Biodiversity, family income and ecological niche: a study on the consumption of animal foods on Búzios Island (Brazil). Ecology of Food and Nutrition, 30(1), 5161. doi:10.1080/03670244.1993.9991322.

Belcher, B., Ruiz-Perez, M., \& Achdiawan, R. (2005). Global patterns and trends in the use and management of commercial NTFPs: implications for livelihoods and conservation. World Development, 33(9), 1435-1452.

Belton, B., \& Thilsted, S. H. (2014). Fisheries in transition: food and nutrition security implications for the global South. Global Food Security, 3(1), 59-66. doi:10.1016/j.gfs.2013.10.001.

Belton, B., van Asseldonk, I. J. M., \& Thilsted, S. H. (2014). Faltering fisheries and ascendant aquaculture: implications for food and nutrition security in Bangladesh. Food Policy, 44, 77-87. doi:10.1016/ j.foodpol.2013.11.003.

Berti, P. R., \& Jones, A. D. (2013). Biodiversity's contribution to dietary diversity. In J. C. Fanzo, D. Hunter, T. Borelli, \& F. Mattei (Eds.), Diversifying food and diets: using agricultural biodiversity to improve nutrition and health ( $\mathrm{p} 400$ ). Abingdon: Routledge.

Berti, P. R., Krasevec, J., \& Fitzgerald, S. (2004). A review of the effectiveness of agriculture interventions in improving nutrition outcomes. Public Health Nutrition, 7(5), 599-609.

Bharucha, Z., \& Pretty, J. (2010). The roles and values of wild foods in agricultural systems. Philosophical Transactions of the Royal Society, B: Biological Sciences, 365(1554), 2913-2926. doi:10.1098/rstb.2010.0123.

Blaney, S., Beaudry, M., \& Latham, M. (2009). Contribution of natural resources to nutritional status in a protected area of Gabon. Food \& Nutrition Bulletin, 30(1), 49-62.

Bloem, M. W., Huq, N., Gorstein, J., Burger, S., Kahn, T., Islam, N., et al. (1996). Production of fruits and vegetables at the homestead is an 
important source of vitamin A among women in rural Bangladesh. European Journal of Clinical Nutrition, 50(Suppl 3), S62-S67.

Boedecker, J., Termote, C., Assogbadjo, A., Van Damme, P., \& Lachat, C. (2014). Dietary contribution of Wild Edible Plants to women's diets in the buffer zone around the Lama forest, Benin - an underutilized potential. Food Security, 6(6), 833-849. doi:10.1007/ s12571-014-0396-7.

Boeing, H., Bechthold, A., Bub, A., Ellinger, S., Haller, D., Kroke, A., et al. (2012). Critical review: vegetables and fruit in the prevention of chronic diseases. European Journal of Nutrition, 51(6), 637-663. doi:10.1007/s00394-012-0380-y.

Brookfield, H. (2002). Agrodiversity and agrobiodiversity. In H. Brookfield, C. Padoch, H. Parsons, \& M. Stocking (Eds.), Cultivating diversity, understanding analysis and using agricultural diversity. London: ITDG Publishing.

Brun, T., Reynaud, J., \& Chevassus-Agnes, S. (1989). Food and nutritional impact of one home garden project in Senegal. Ecology of Food and Nutrition, 23(2), 91-108. doi:10.1080/03670244.1989.9991092.

Burlingame, B., \& Dernini, S. (2012). Sustainable diets and biodiversity: Directions and solutions for policy, research and action. Rome: FAO.

Burlingame, B., Charrondiere, R., \& Mouille, B. (2009). Food composition is fundamental to the cross-cutting initiative on biodiversity for food and nutrition. Journal of Food Composition and Analysis, 22(5), 361-365. doi:10.1016/j.jfca.2009.05.003.

Bushamuka, V. N., de Pee, S., Talukder, A., Kiess, L., Panagides, D., Taher, A., et al. (2005). Impact of a homestead gardening program on household food security and empowerment of women in Bangladesh. Food \& Nutrition Bulletin, 26(1), 17-25.

Campbell, B. M. (1987). The use of wild fruits in Zimbabwe. Economic Botany, 41(3), 375-385.

Cerda, R., Deheuvels, O., Calvache, D., Niehaus, L., Saenz, Y., Kent, J., et al. (2014). Contribution of cocoa agroforestry systems to family income and domestic consumption: looking toward intensification. Agroforestry Systems, 1-25. doi:10.1007/s10457-014-9691-8.

Chadwick, P. M., Crawford, C., \& Ly, L. (2013). Human food choice and nutritional interventions. Nutrition Bulletin, 38(1), 36-42. doi:10. 1111/nbu.12005.

Chweya, J. A., \& Eyzaguirre, P. B. (1999). The biodiversity of traditional leafy vegetables. Rome: International Plant Genetic Resource Institute.

Clarke, J. M. (1983). A socio-ecological study of a rural community in the northern Sebungwe. MSc Thesis, University of Zimbabwe.

Colding, J., \& Folke, C. (2001). Social taboos: "invisable" systems of local resource management and biological conservation. Ecological Applications, 11(2), 584-600.

Colfer, C. P., \& Soedjito, H. (2008). The longhouse of the Tarsier: Changing landscapes, gender and well being in Borneo. Borneo research council monograph series, volume 10. Swidden Transformations and Rural Livelihoods in Southeast Asia: Borneo Research Council, Inc.

Coomes, O., \& Ban, N. (2004). Cultivated plant species diversity in home gardens of an Amazonian peasant village in Northeastern Peru. Economic Botany, 58(3), 420-434. doi:10.1663/0013-0001(2004) $058[0420$ :cpsdih $] 2.0$. co; 2 .

daSilva, A., \& Begossi, A. (2009). Biodiversity, food consumption and ecological niche dimension: a study case of the riverine populations from the Rio Negro, Amazonia, Brazil. Environment, Development and Sustainability, 11(3), 489-507. doi:10.1007/s10668-007-9126-z.

de Merode, E., Homewood, K., \& Cowlishaw, G. (2004). The value of bushmeat and other wild foods to rural households living in extreme poverty in Democratic Republic of Congo. Biological Conservation, 118(5), 573-581. doi:10.1016/j.biocon.2003.10.005.

Dei, G. J. S. (1989). Hunting and gathering in a Ghanaian rain forest community. Ecology of Food and Nutrition, 22(3), 225-243. doi: 10.1080/03670244.1989.9991071.
Dewey, K. (1981). Nutritional consequences of the transformation from subsistence to commercial agriculture in Tabasco, Mexico. Human Ecology, 9(2), 151-187. doi:10.1007/bf00889132.

do Nascimento, V. T., de Lucena, R. F. P., Maciel, M. I. S., \& de Albuquerque, U. P. (2013). Knowledge and use of wild food plants in areas of dry seasonal forests in Brazil. Ecology of Food and Nutrition, 52(4), 317-343. doi:10.1080/03670244.2012.707434.

Dounias, E., Selzner, A., Koizumi, M., \& Levang, P. (2007). From sago to rice, from forest to town: The consequences of sedentarization for the nutritional ecology of Punan former hunter-gatherers of Borneo. Food and Nutrition Bulletin, 28(2, supplement), online.

Dufour, D. L. (1992). Nutritional ecology in the tropical rain forests of Amazonia. American Journal of Human Biology, 4(2), 197-207. doi:10.1002/ajhb.1310040205.

Dufour, C., Kauffmann, D., \& Marsland, N. (2014). Strengthening the links between resilience and nutrition: A proposed approach (Vol. 18): Intl Food Policy Res Inst.

Dwyer, P. D. (1985). The contribution of non-domesticated animals to the diet of Etolo, southern highlands province, Papua New Guinea. Ecology of Food and Nutrition, 17(2), 101-115. doi:10.1080/ 03670244.1985.9990885.

Ekesa, B. N., Walingo, M. K., \& Abukutsa-Onyango, M. O. (2008). Influence of agricultural biodiversity on dietary diversity of preschool children in Matungu division, western Kenya. African Journal of Food, Agriculture, Nutrition and Development, online.

Ellen, R. O. Y. (2006). Local knowledge and management of Sago Palm (Metroxylon sagu Rottboell) diversity in South Central Seram, Maluku, Eastern Indonesia. Journal of Ethnobiology, 26(2), 258 298. doi:10.2993/0278-0771(2006)26[258:1kamos]2.0.co;2.

Etkin, N. L. (2009). Foods of association: Biocultural perspectives on food, beverages, and association. Tucson: University of Arizona Press.

Eyzaguirre, P. B., \& Linares, O. F. (Eds.). (2010). Home gardens and agrobiodiversity. Washington: Smithsonian Books.

Faber, M., Phungula, M. A., Venter, S. L., Dhansay, M. A., \& Benadé, A. S. (2002). Home gardens focusing on the production of yellow and dark-green leafy vegetables increase the serum retinol concentrations of 2-5-y-old children in South Africa. The American Journal of Clinical Nutrition, 76(5), 1048-1054.

FAO, \& FANTA (2007). Guidelines for measuring household and individual dietary diversity. Rome, Italy: Food and Agriculture Organization of the United Nations (FAO) the Food and Nutrition Technical Assistance (FANTA) Project.

FAO (2013). Edible forest insects, http://www.fao.org/forestry/ edibleinsects/en.

Fischler, C. (1988). Food, self and identity. Social Science Information, 27(2), 275-292.

Fleuret, A. (1979). The role of wild foliage plants in the diet: a case study from Lushoto, Tanzania. Ecology of Food and Nutriton, 8, 87-93.

Foli, S., Reed, J., Clendenning, J., Petrokofsky, G., Padoch, C., \& Sunderland, T. (2014). To what extent does the presence of forests and trees contribute to food production in humid and dry forest landscapes?: a systematic review protocol. Environmental Evidence, 3(1), 15.

Frison, E. A., Cherfas, J., \& Hodgkin, T. (2011). Agricultural biodiversity Is essential for a sustainable improvement in food and nutrition security. Sustainability, 3(1), 238-253.

Garibaldi, A., \& Turner, N. (2004). Cultural keystone species: implications for ecological conservation and restoration. Ecology and Society, 9(3), 1-18.

Gibson, R., Hotz, C., Temple, L., Yeudall, F., Mtitimuni, B., \& Ferguson, E. (2000). Dietary strategies to combat deficiency of iron, zinc and vitamin A in developing countries: development, implementation, monitoring and evaluation. Food and Nutrition Bulletin, 21(2), 219223. 
Gibson, R. S., Perlas, L., \& Hotz, C. (2006). Improving the bioavailability of nutrients in plant foods at the household level. Proceedings of the Nutrition Society, 65(2), 160-168.

Girard, A. W., Self, J. L., McAuliffe, C., \& Olude, O. (2012). The effects of household food production strategies on the health and nutrition outcomes of women and young children: a systematic review. Paediatric and Perinatal Epidemiology, 26, 205-222. doi:10.1111/ j.1365-3016.2012.01282.x.

Glanz, K., Sallis, J. F., Saelens, B. E., \& Frank, L. D. (2005). Healthy nutrition environments: concepts and measures. American Journal of Health Promotion, 19(5), 330-333. doi:10.4278/0890-1171-19.5. 330.

Greenberg, L. (2003). Women in the garden and kitchen: The role of cuisine in the conservation of traditional house lot crops among the Yucatec Mayan immigrants. In P. L. Howard (Ed.), Women and plants: Gender relations in biodiversity management and conservation. London: Zed Books.

Grivetti, L. E., \& Ogle, B. M. (2000). Value of traditional foods in meeting macro- and micronutrient need: the wild plant connection. Nutrition Research Reviews, 13, 31-46.

Hadjichambis, A. C. H., Paraskeva-Hadjichambi, D., Della, A., Elena Giusti, M., De Pasquale, C., Lenzarini, C., et al. (2008). Wild and semi-domesticated food plant consumption in seven circum-Mediterranean areas. International Journal of Food Sciences and Nutrition, 59(5), 383-414. doi:10.1080/ 09637480701566495.

Hall, J. N., Moore, S., Harper, S. B., \& Lynch, J. W. (2009). Global variability in fruit and vegetable consumption. American Journal of Preventive Medicine, 36(5), 402-409.e405. doi:10.1016/j. amepre.2009.01.029.

Halwart, M. (2006). Biodiversity and nutrition in rice-based aquatic ecosystems. Journal of Food Composition and Analysis, 19(6-7), 747751. doi:10.1016/j.jfca.2006.03.012.

Hanazaki, N., \& Begossi, A. (2003). Does fish still matter? Canges in the diet of two brazilian fishing communities. Ecology of Food and Nutrition, 42(4-5), 279-301. doi:10.1080/03670240390229643.

Harden, J., Duvick, D., \& Visser, B. (2000). Genetic diversity, conservation and development. In C. Almekinders \& W. De Boef (Eds.), Encouraging diversity. London: Intermediate Technology Publications.

Harden-Baars, A. (2000). The role of agrobiodiversity in farm-house livelihood and food security: A conceptual analysis. In C. Almekinders \& W. De Boef (Eds.), Encouraging Diversity: The conservation and development of plant genetic resources (pp. 3135). London: Intermediate Technology Publications.

Haug, A., Christophersen, O., Kinabo, J., Kaunda, W., \& Eik, L. (2010). Use of dried Kapenta (Limnothrissa miodon and Stolothrissa tanganicae) and other products based on whole fish for complementing maize-based diets. African Journal of Food, Agriculture, Nutrition and Development, 10(5).

Hawkes, C. (2013). Promoting healthy diets through nutrition education and changes in the food environment: An international review of actions and their effectiveness. Rome: Nutrition Education and Consumer Awareness Group, Food and Agriculture Organization of the United Nations.

Herforth, A. (2010). Promotion of traditional African vegetables in Kenya and Tanzania: A case study of an intervention representing emerging imperatives in global nutrition. $\mathrm{PhD}$ Thesis, Cornell University.

Herforth, A., \& Ahmed, S. (2015). The food environment, its effects on dietary consumption, and potential for measurement within agriculture-nutrition interventions. Food Security. doi:10.1007/s12571015-0455-8.
Herforth, A., \& Dufour, C. (2013). key recommendations for improving nutrition through agriculture: establishing a global consensus. SCN News, 40, 33-38.

Herforth, A., \& Harris, J. (2014). Understanding and Applying Primary Pathways and Principles. Brief \#1. Improving Nutrition through Agriculture Technical Brief Series (Vol. 50, pp. 48-61). Arlington, VA: USAID/Strengthening Partnerships, Results, and Innovations in Nutrition Globally (SPRING) Project.

Herzog, F., Farah, Z., \& Amadò, R. (1994). Composition and consumption of gathered wild fruits in the V-Baoulé, Côte d'Ivoire. Ecology of Food and Nutrition, 32(3-4), 181-196. doi:10.1080/03670244. 1994.9991399.

Heywood, V. H. (2013). Overview of agricultural biodiversity and its contribution to nutrition and health. In D. Hunter, T. Borelli, F. Mattei, \& J. Fanzo (Eds.), Diversifying Food and Diets Using Agricultural Biodiversity to Improve Nutrition and Health. (pp. 384): Earthscan from Routledge.

Hoffmann, I. (2003). Transcending reductionism in nutrition research. The American Journal of Clinical Nutrition, 78(3), 514S-516S.

Humphry, C. M., Clegg, M. S., Keen, C. L., \& Grivetti, L. E. (1993). Food diversity and drought survival. The Hausa example. International Journal of Food Sciences and Nutrition, 44(1), 116. doi:10.3109/09637489309017417.

Hunter, D., \& Fanzo, J. C. (2013). Introduction: Agricultural biodiversity, diverse diets and improving nutrition. In J. Fanzo, D. Hunter, T. Borelli, \& F. Mattei (Eds.), Diversifying food and diets Using agricultural biodiversity to improve nutrition and health: Earthscan from Routledge.

Hurtado, A. M., \& Hill, K. R. (1987). Early dry season subsistence ecology of Cuiva (Hiwi) foragers of Venezuela. Human Ecology, 15(2), 163-187. doi:10.2307/4602839.

Huss-Ashmore, R., \& Curry, J. J. (1991). Diet, nutrition, and agricultural development in Swaziland. 2. Patterns of food consumption. Ecology of Food and Nutrition, 26(3), 167-185. doi:10.1080/ 03670244.1991 .9991200

Iannotti, L., \& Lesorogol, C. (2014). Dietary intakes and micronutrient adequacy related to the changing livelihoods of two pastoralist communities in Samburu, Kenya. Current Anthropology, 55(4), 475482. doi:10.1086/677107.

Ickowitz, A., Powell, B., Salim, M. A., \& Sunderland, T. (2014). Dietary quality and tree cover in Africa. Global Environmental Change, 24, 287-294.

Ickowitz, A., Rowland, D., Powell, B., \& Sunderland, T. C. H. (under review). Forests, trees, and micronutrient-rich food consumption in Indonesia.

ISPC (2014). Nutrition and health outcomes: Targets for agricultural research. Insights and recommendations from the CGIAR Science Forum 2013. (Vol. Brief Number 43, pp. 8). Rome, Italy: Independent Science and Partnership Council, CGIAR.

Jamnadass, R. H., Place, F., Torquebiau, E., Malézieux, E., Iiyama, M., Sileshi, G. W., et al. (2013). Agroforestry for food and nutritional security. Unasylva, 214(64), 23-29.

Johns, T., \& Sthapit, B. R. (2004). Biocultural diversity in the sustainability of developing-country food systems. Food and Nutrition Bulletin, 25(2), 143-155.

Johns, T., Mahunnah, R. L. A., Sanaya, P., Chapman, L., \& Ticktin, T. (1999). Saponins and phenolic content in plant dietary additives of a traditional subsistence community, the Batemi of Ngorongoro District, Tanzania. Journal of Ethnopharmacology, 66(1), 1-10. doi:10.1016/S0378-8741(98)00179-2.

Johns, T., Powell, B., Maundu, P., \& Eyzaguirre, P. B. (2013). Agricultural biodiversity as a link between traditional food systems and contemporary development, social integrity and ecological health. Journal of the Science of Food and Agriculture, 93(14), 3433-3442. doi:10.1002/jsfa.6351. 
Johnson, N., \& Grivetti, L. (2002). Environmental change in northern Thailand: impact on wild edible plant availability. Ecology of Food and Nutrition, 41, 373-399.

Johnson, K. B., Jacob, A., \& Brown, M. E. (2013). Forest cover associated with improved child health and nutrition: evidence from the Malawi Demographic and Health Survey and satellite data. Global Health: Science and Practice, 1(2), 237-248. doi:10.9745/ghsp-d-13-00055.

Jones, A. D., Cruz Agudo, Y., Galway, L., Bentley, J., \& PinstrupAndersen, P. (2012). Heavy agricultural workloads and low crop diversity are strong barriers to improving child feeding practices in the Bolivian Andes. Social Science \& Medicine, 75(9), 1673-1684. doi:10.1016/j.socscimed.2012.06.025.

Jones, A. D., Shrinivas, A., \& Bezner-Kerr, R. (2014). Farm production diversity is associated with greater household dietary diversity in Malawi: findings from nationally representative data. Food Policy, 46, 1-12. doi:10.1016/j.foodpol.2014.02.001.

Katz, E., López, C. L., Fleury, M., Miller, R. P., Payê, V., Dias, T., et al. (2012). No greens in the forest? Note on the limited consumption of greens in the Amazon. Acta Societatis Botanicorum Poloniae, 81(4), 283-293.

Keding, G., Msuya, J., Maass, B., \& Krawinkel, M. (2012). Relating dietary diversity and food variety scores to vegetable production and socio-economic status of women in rural Tanzania. Food Security, 4(1), 129-140. doi:10.1007/s12571-011-0163-y.

Kehlenbeck, K., Arifin, H. S., \& Maass, B. L. (2007). Plant diversity in homegardens in a socio-economic and agro-ecological context. In T. Tscharntke, C. Leuschner, M. Zeller, E. Guhardja, \& A. Bidin (Eds.), Stability of tropical rainforest margins: Linking ecological, economic and social constraints (pp. 297-319). Germany: Environmental Science Series, Springer.

Kehlenbeck, K., Asaah, E., \& Jamnadass, R. (2013). Diversity of indigenous fruit trees and their contribution to nutrition and livelihoods in sub-Saharan Africa: examples from Kenya and Cameroon. In J. C. Fanzo, D. Hunter, T. Borelli, \& F. Mattei (Eds.), Diversifying food and diets Using agricultural biodiversity to improve nutrition and health: Earthscan from Routledge.

Kennedy, G., Ballard, T., \& Dop, M. C. (2011). Guidelines for measuring household and individual dietary diversity. Rome: Food and Agriculture Organization of the United Nations (FAO).

Khare, R. S. (1980). Food as nutrition and culture, Notes towards an anthropological methodology. Social Science Information, 19(3), 519-542.

Khoury, C. K., Bjorkman, A. D., Dempewolf, H., Ramirez-Villegas, J., Guarino, L., Jarvis, A., et al. (2014). Increasing homogeneity in global food supplies and the implications for food security. Proceedings of the National Academy of Sciences, 111(11), 40014006. doi:10.1073/pnas.1313490111.

Kuhnlein, H. V. (2009). Introduction: Why are Indigenous Peoples' food systems important and why do they need documentation? In H. V. Kuhnlein, B. Erasmus, \& D. Spigelski (Eds.), Indigenous Peoples' food systems: The many dimensions of culture, diversity and environment for nutrition and health. Rome: Food and Agriculture Organization of the United Nations and the Centre for Indigenous Peoples' Nutrition and Environment.

Kuhnlein, H. V., \& Receveur, O. (1996). Dietary change and traditional food systems of indigenous peoples. Annual Review of Nutrition, 16, 417-442.

Leroy, J. L., \& Frongillo, E. A. (2007). Can interventions to promote animal production ameliorate undernutrition? The Journal of Nutrition, 137(10), 2311-2316.

Macdiarmid, J. I. (2013). Is a healthy diet an environmentally sustainable diet? Proceedings of the Nutrition Society, 72(01), 13-20. doi:10. 1017/S0029665112002893.

Macdiarmid, J. I., Kyle, J., Horgan, G. W., Loe, J., Fyfe, C., Johnstone, A., et al. (2012). Sustainable diets for the future: can we contribute to reducing greenhouse gas emissions by eating a healthy diet? The American Journal of Clinical Nutrition, 96(3), 632-639. doi:10. 3945/ajen.112.038729.

Marteau, T. M., Hollands, G. J., \& Fletcher, P. C. (2012). Changing human behavior to prevent disease: the importance of targeting automatic processes. Science, 337(6101), 1492-1495. doi:10.1126/ science. 1226918.

Masset, E., Haddad, L., Cornelius, A., \& Isaza-Castro, J. (2012). Effectiveness of agricultural interventions that aim to improve nutritional status of children: systematic review. $B M J, 344$, doi:10. 1136/bmj.d8222.

McBurney, R. P. H., Griffin, C., Paul, A. A., \& Greenberg, D. C. (2004). The nutritional composition of African wild food plants: from compilation to utilization. Journal of Food Composition and Analysis, 17(3-4), 277-289. doi:10.1016/j.jfca.2004.03.008.

McGuire, S. (2008). Securing access to seed: social relations and sorghum seed exchange in Eastern Ethiopia. Human Ecology, 36(2), 217-229. doi:10.1007/s10745-007-9143-4.

MillenniumEcosystemAssessment. (2005). Ecosystems and human well-being: Health synthesis and biodiversity synthesis. Geneva: WHO (world Health Organization), World Research Institute.

Moreno-Black, G., \& Somnasang, P. (2000). In times of plenty and times of scarcity: nondomesticated food in north-eastern Thailand. Ecology of Food and Nutrition, 38(6), 563-586.

Mourão, F. A. A. (1971). Os pescadores do Litoral Sul do Estado de São Paulo: Um estudo de sociologia diferencial. Brazil: University of São Paulo.

Murphy, S. P., \& Allen, L. A. (2003). Nutritional importance of animal source foods. Journal of Nutrition, 133, 3932S-3935S.

Murrieta, R. S. S., Dufour, D. L., \& Siqueira, A. D. (1999). Food consumption and subsistence in three caboclo populations on Marajó Island, Amazonia, Brazil. Human Ecology, 27(3), 455-475. doi:10. 2307/4603329.

Nasi, R., Brown, D., Wilkie, D., Bennett, E., Tutin, C., van Tol, G., et al. (2008). Conservation and use of wildlife-based resources: the bushmeat crisis. (pp. 50). Bogor: Technical Series no. 33, Secretariat of the Convention on Biological Diversity, Montreal, and Center for International Forestry Research (CIFOR).

Nasi, R., Taber, A., \& Vliet, N. V. (2011). Empty forests, empty stomachs? Bushmeat and livelihoods in the Congo and Amazon Basins. International Forestry Review, 13(3), 355-368. doi:10. 1505/146554811798293872.

Newman, J. L. (1975). Dimensions of Sandawe diet. Ecology of Food and Nutrition, 4(1), 33-39. doi:10.1080/03670244.1975.9990404.

Ngugi, I., Gitau, R., \& Nyoro, J. (2007). Access to high value markets by smallholder farmers of African indigenous vegetables in Kenya. London: Regoverning Markets Innovative Practice series, IIED.

Nielsen, M. R. (2006). Importance, cause and effect of bushmeat hunting in the Udzungwa Mountains, Tanzania: implications for community based wildlife management. Biological Conservation, 128, 509516.

Ogle, B., Hung, P., \& Tuyet, H. (2001). Significance of wild vegetables in micronutrient intakes of women in Vietnam: an analysis of food variety. Asia Pacific Journal of Clinical Nutrition, 10(1), 21-30.

Oyarzun, P. J., Borja, R. M., Sherwood, S., \& Parra, V. (2013). Making sense of agrobiodiversity, diet, and intensification of smallholder family farming in the highland Andes of Ecuador. Ecology of Food and Nutrition, 52(6), 515-541. doi:10.1080/03670244.2013. 769099. 
Padoch, C., \& Sunderland, T. (2013). Managing landscapes for greater food security and improved livelihoods. Unasylva, 214(64), 3-13.

Pardo-De-Santayana, M., Tardío, J., \& Morales, R. (2005). The gathering and consumption of wild edible plants in the Campoo (Cantabria, Spain). International Journal of Food Sciences and Nutrition, 56(7), 529-542. doi:10.1080/09637480500490731.

Parlesak, A., Geelhoed, D., \& Robertson, A. (2014). Toward the prevention of childhood undernutrition: diet diversity strategies using locally produced food can overcome gaps in nutrient supply. Food \& Nutrition Bulletin, 35(2), 191-199.

Penafiel, D., Lachat, C., Espinel, R., Van Damme, P., \& Kolsteren, P. (2011). A systematic review on the contributions of edible plant and animal biodiversity to human diets. EcoHealth, 8(3), 1-19. doi:10.1007/s10393-011-0700-3.

Pieroni, A., Nebel, S., Santoro, R. F., \& Heinrich, M. (2005). Food for two seasons: culinary uses of non-cultivated local vegetables and mushrooms in a south Italian village. International Journal of Food Science and Nutrition, 56(4), 245-272.

Pimentel, D., McNair, M., Buck, L., Pimentel, M., \& Kamil, J. (1997). The value of forests to world food security. Human Ecology, 25(1), 91-120. doi:10.1023/a:1021987920278.

Pinstrup-Andersen, P. (2010). The African food system and its interactions with human health and nutrition. Ithica: Cornell University Press.

Pinstrup-Andersen, P. (2013a). Can agriculture meet future nutrition challenges? European Journal of Development Research, $25,5-12$.

Pinstrup-Andersen, P. (2013b). Nutrition-sensitive food systems: from rhetoric to action. The Lancet, 382(9890), 375-376.

Powell, B. (2012). Biodiversity and human nutrition in a landscape mosaic of farms and forests in the East Usambara Mountains. Tanzania: McGill University, Montreal, Canada.

Powell, B., Watts, J., Boucard, A., Urech, Z., Feintrenie, L., Lyimo, E., et al. (2010). The role of wild species in the governance of tropical forested landscapes, Chapter 7. In C. J. P. Colfer \& J.-L. Pfund (Eds.), Collaborative governance of tropical landscapes. London: Earthscan.

Powell, B., Hall, J., \& Johns, T. (2011). Forest cover, use and dietary intake in the East Usambara Mountains, Tanzania. International Forestry Review, 13(3), online.

Powell, B., Ickowitz, A., McMullin, S., Jamnadass, R., Padoch, C., Pinedo-Vasquez, M., et al. (2013a). The role of forests, trees and wild biodiversity for improved nutrition-sensitivity of food and agriculture systems. Expert background paper for the International Conference on Nutrition 2. Rome, Italy.

Powell, B., Maundu, P., Kuhnlein, H. V., \& Johns, T. (2013b). Wild foods from farm and forest in the East Usambara Mountains, Tanzania. Ecology of Food and Nutrition, 52(6), 451-478. doi:10.1080/ 03670244.2013 .768122 .

Powell, B., Ouarghidi, A., Johns, T., Ibn Tattou, M., \& Eyzaguirre, P. (2014). Wild leafy vegetable use and knowledge across multiple sites in Morocco: a case study for transmission of local knowledge? Journal of Ethnobiology and Ethnomedicine, 10(1), 34.

Price, L. L. (1997). Wild plant food in agricultural environments: a study of occurrence, management, and gathering rights in Northeast Thailand. Human Organization, 56(2), 209-221.

Qaim, M., Andersson, C. I., Chege, C. G., Kimenju, S. C., Klasen, S., \& Rischke, R. (2014). Nutrition effects of the supermarket revolution on urban consumers and smallholder farmers in Kenya. GlobalFood Discussion Papers.
Randolph, T. F., Schelling, E., Grace, D., Nicholson, C. F., Leroy, J. L., Cole, D. C., et al. (2007). Invited review: role of livestock in human nutrition and health for poverty reduction in developing countries. Journal of Animal Science, 85(11), 2788-2800. doi:10.2527/jas. 2007-0467.

Remans, R., Flynn, D. F. B., DeClerck, F., Diru, W., Fanzo, J., Gaynor, K., et al. (2011). assessing nutritional diversity of cropping systems in African villages. PloS One, 6(6), e21235. doi:10.1371/journal. pone.0021235

Remans, R., Wood, S. A., Saha, N., Anderman, T. L., \& DeFries, R. S. (2014). Measuring nutritional diversity of national food supplies. Global Food Security, online first.

Ross, E. B., Arnott, M. L., Basso, E. B., Beckerman, S., Carneiro, R. L., Forbis, R. G., et al. (1978). Food Taboos, diet, and hunting strategy: the adaptation to animals in amazon cultural ecology [and Comments and Reply]. Current Anthropology, 19(1), 1-36. doi: $10.2307 / 2741146$

Ruel, M. T. (2003). Operationalizing dietary diversity: a review of measurement issues and research priorities. Journal of Nutrition, 133(11 Suppl 2), 3911S-3926S

Ruel, M. T., \& Alderman, H. (2013). Nutrition-sensitive interventions and programmes: how can they help to accelerate progress in improving maternal and child nutrition? The Lancet, 382, 536-51. doi: 10.1016/S0140-6736(13)60843-0.

Sasaoka, M., Laumonier, Y., \& Sugimura, K. (2014). Influence of Indigenous Sago-based agriculture on local forest landscapes in Maluku, East Indonesia. Journal of Tropical Forest Science, 26(1), 75-83. doi:10.2307/23617016.

Sayer, J., Sunderland, T., Ghazoul, J., Pfund, J.-L., Sheil, D., Meijaard, E., et al. (2013). Ten principles for a landscape approach to reconciling agriculture, conservation, and other competing land uses. Proceedings of the National Academy of Sciences, 110(21), 83498356. doi:10.1073/pnas.1210595110.

Schlegel, S. A., \& Guthrie, H. A. (1973). Diet and the tiruray shift from swidden to plow farming. Ecology of Food and Nutrition, 2(3), 181191. doi:10.1080/03670244.1973.9990335.

Scoones, I., \& Bishop, J. (1994). The hidden harvest: The role of wild foods in agricultural systems. IIED Research Series Vol. 3, No. 1 (pp. 49). London: International Institute for Environment and Development.

Shiundu, K., \& Oniang'o, R. (2007). Marketing African leafy vegetables: Challenges and opportunities in the Kenyan context. African Journal of Food Agriculture Nutrition and Development, 7(4), online.

Siegel, K. R., Ali, M. K., Srinivasiah, A., Nugent, R. A., \& Narayan, K. M. V. (2014). Do we produce enough fruits and vegetables to meet global health need? PloS One, 9(8), e104059. doi:10.1371/journal. pone. 0104059 .

Sobal, J., Bisogni, C. A., \& Jastran, M. (2014). Food choice is multifaceted, contextual, dynamic, multilevel, integrated, and diverse. Mind, Brain, and Education, 8(1), 6-12. doi:10.1111/mbe.12044.

Stadlmayr, B., Charrondière, U. R., Eisenwagen, S., Jamnadass, R., \& Kehlenbeck, K. (2013). Nutrient composition of selected indigenous fruits from sub-Saharan Africa. Journal of the Science of Food and Agriculture, 93(11), 2627-2636. doi:10. 1002/jsfa.6196.

Story, M., Kaphingst, K. M., Robinson-O’Brien, R., \& Glanz, K. (2008). Creating healthy food and eating environments: policy and environmental approaches. Annual Review of Public Health, 29(1), 253-272. doi:10.1146/annurev.publhealth.29. 020907.090926.

Sunderland, T. C. H. (2011). Food security: why is biodiversity important? International Forestry Review, 13(3), online. 
Sunderland, T., Powell, B., Ickowitz, A., Foli, S., Pinedo-Vasquez, M., Nasi, R., et al. (2013). Food security and nutrition: The role of forests. Discussion Paper. Bogor, Indonesia: CIFOR.

Sunderlin, W. D., Dewi, S., Puntodewo, A., Müller, D., Angelsen, A., \& Epprecht, M. (2008). Why forests are important for global poverty alleviation: a spatial explanation. Ecology and Society, 13(2), 24

Swinburn, B., Sacks, G., Vandevijvere, S., Kumanyika, S., Lobstein, T., Neal, B., et al. (2013). INFORMAS (International Network for Food and Obesity/non-communicable diseases Research, Monitoring and Action Support): overview and key principles. Obesity Reviews, 14, 1-12. doi:10.1111/obr.12087.

Termote, C., Bwama Meyi, M., Dhed'a Djailo, B., Huybregts, L., Lachat, C., Kolsteren, P., et al. (2012). A biodiverse rich environment does not contribute to a better diet: a case study from DR Congo. PloS One, 7(1), e30533. doi:10.1371/journal.pone.0030533.

Termote, C., Raneri, J., Deptford, A., \& Cogill, B. (2014). Assessing the potential of wild foods in reducing the cost of a nutritionally adequate diet - An example from eastern Baringo District, Kenya. Food and nutrition bulleting.

Thilsted, S. H. (2013). Fish diversity and fish consumption in Bangladesh. Diversifying Food and Diets: Using Agricultural Biodiversity to Improve Nutrition and Health, 270.

Thilsted, S., Burlingame, B., \& Dernini, S. (2012). Improved management, increased culture and consumption of small fish species can improve diets of the rural poor. In Sustainable Diets and Biodiversity: Directions and Solutions for Policy, Research and Action. International Scientific Symposium, Biodiversity and Sustainable Diets United Against Hunger, FAO Headquarters, Rome, Italy, 3-5 November 2010.(pp. 176-181): Food and Agricultre Organization of the United Nations (FAO).

Thilsted, S., Subasinghe, R., Arthur, J., Bartley, D., De Silva, S., Halwart, M., et al. (2013). The potential of nutrient-rich small fish species in aquaculture to improve human nutrition and health. In Proceedings of the Global Conference on Aquaculture 2010. Farming the waters for people and food. (pp. 57-73): FAO/NACA.

Ticktin, T. (2004). The ecological implications of harvesting non-timber forest products. Journal of Applied Ecology, 41(1), 11-21. doi:10. 1111/j.1365-2664.2004.00859.x.

Toledo, Á., \& Burlingame, B. (2006). Biodiversity and nutrition: a common path toward global food security and sustainable development. Journal of Food Composition and Analysis, 19(6-7), 477-483. doi: 10.1016/j.jfca.2006.05.001.

Tontisirin, K., Nantel, G., \& Bhattacharjee, L. (2002). Food-based strategies to meet the challenges of micronutrient malnutrition in the developing world. Proceedings of the Nutrition Society, 61(2), 243-250.

Torheim, L. E., Ouattara, F., Diarra, M. M., Thiam, F. D., Barikmo, I., Hatloy, A., et al. (2004). Nutrient adequacy and dietary diversity in rural Mali: association and determinants. European Journal of Clinical Nutrition, 58(4), 594-604.

Turner, N. J., Łuczaj, Ł., Migliorini, P., Pieroni, A., Dreon, A. L., Sacchetti, L. E., et al. (2011). Edible and tended wild plants, traditional ecological knowledge and agroecology. Critical Reviews in Plant Sciences, 30(1-2), 198-225.

van Liere, M. J., Ategbo, E.-A. D., Den Hartog, A. P., \& Hautvast, J. G. A. J. (1995). The consequences of seasonal food insecurity for individual food-consumption patterns in north-western Benin. Food and Nutrition Bulletin, 16(2), online.

van Vliet, N., Milner-Gulland, E. J., Bousquet, F., Saqalli, M., \& Nasi, R. (2010). Effect of small-scale heterogeneity of prey and hunter distributions on the sustainability of bushmeat hunting. Conservation Biology, 24(5), 1327-1337.

Vinceti, B., Termote, C., Ickowitz, A., Powell, B., Kehlenbeck, K., \& Hunter, D. (2013). The contribution of forests and trees to sustainable diets. Sustainability, 5(11), 4797-4824.

Wadley, R., \& Colfer, C. P. (2004). Sacred forest, hunting, and conservation in West Kalimantan, Indonesia. Human Ecology, 32(3), 313 338. doi:10.1023/B:HUEC.0000028084.30742.d0.

Wahlqvist, M. L. (2005). Diversification in indigenous and ethnic food culture. Forum of Nutrition, 57, 52-61.

Wansink, B. (2007). Mindless eating: Why we eat more than we think: Random House LLC.

WHO, \& FAO. (2004). Fruit and vegetables for health : Report of a Joint FAO/WHO Workshop, 1-3 September, 2004, Kobe, Japan. Geneva: World Health Organization and Food and Agriculture Organization of the UN.

Yeudall, F., Sebastian, R., Cole, D. C., Ibrahim, S., Lubowa, A., \& Kikafunda, J. (2007). Food and nutritional security of children of urban farmers in Kampala, Uganda. Food \& Nutrition Bulletin, $28(2), 237 \mathrm{~S}-246 \mathrm{~S}$

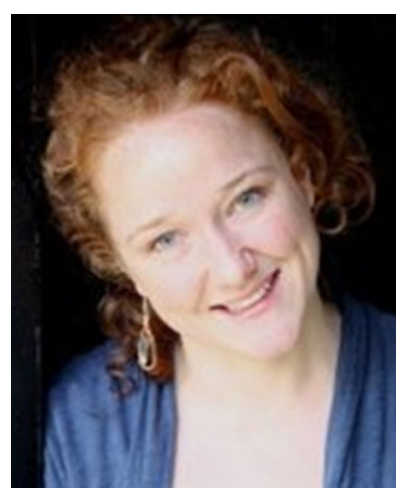

Bronwen Powell Bronwen Powell is a post-doctoral researcher with the Center for International Forestry Research. She holds a $\mathrm{PhD}$ in Human Nutrition from McGill University in Canada and an MSc in Ethnobiology from the Department of Anthropology at the University of Kent, Canterbury, England. She has worked on projects in association with the World Vegetable Center, Bioversity International and other CGIAR centers in Tanzania, Kenya and Morocco. Her research focuses on how wild and cultivated biodiversity contribute to diet and nutrition.

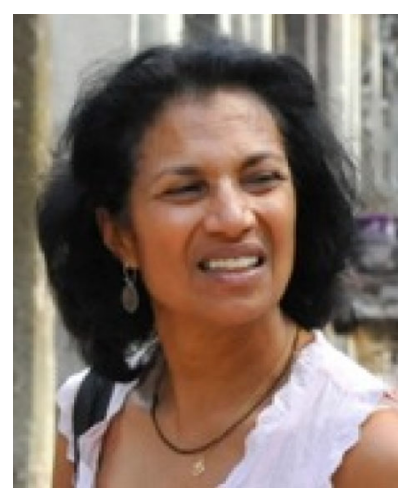

Shakuntala Haraksingh Thilsted Shakuntala Haraksingh Thilsted is Senior Nutrition Scientist at WorldFish, based in Bangladesh. She was formerly with the Department of Human Nutrition, University of Copenhagen, Denmark. Her broad area of research and expertise is foodbased strategies for improved food and nutrition security in low-income countries. She has carried out work in Bangladesh, Cambodia, West Bengal and Nepal, together with government institutions, universities and NGOs, focusing on the potential of nutrientrich small fish in combating and preventing vitamin and mineral deficiencies, in particular, vitamin A, iron, zinc and calcium, especially in women and children. 


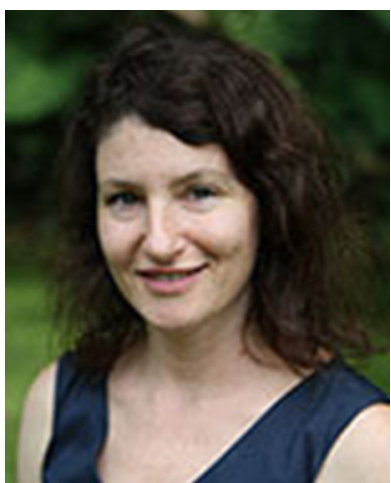

Amy Ickowitz Amy Ickowitz is a scientist in CIFOR's Forests and Livelihoods programme. Prior to joining CIFOR, she was an assistant professor at Clark University, USA. Her research interests are development, natural resource management and health economics. Amy holds a PhD in Economics from the University of California, Riverside, USA

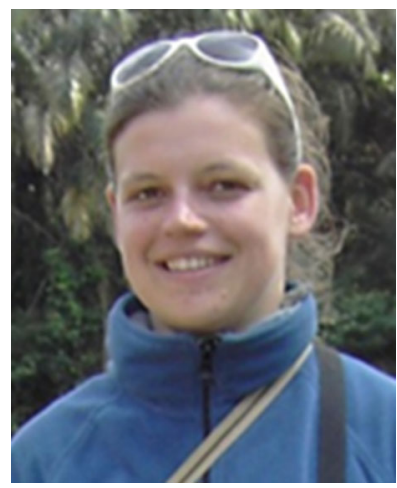

Céline Termote Céline Termote is a scientist at Bioversity International based in Nairobi as part of the Nutrition and Marketing Diversity Programme. After obtaining her Master's degree in Applied Biological Sciences, she started her career as development worker for a Belgian NGO in DRCongo, where she worked with two local partner organizations on food security, sustainable agricultural practices, capacity building and organization strengthening. Her $\mathrm{PhD}$, from the Laboratory of Tropical and Subtropical Agronomy and Ethnobotany at Ghent University, looked at the use of wild edible plants in Tshopo District (Kisangani region), DRCongo.

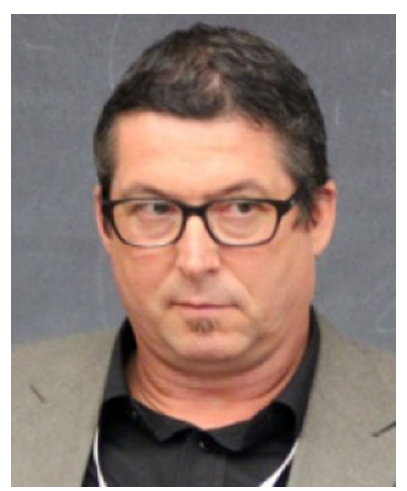

Terry Sunderland Terry Sunderland is a Principle Scientist with CIFOR's Forests and Livelihoods programme, and leads the research domain 'Managing tradeoffs between conservation and development at the landscape scale' and CIFORs growing portfolio on Forests and Food Security. Prior to joining CIFOR, Terry was based in Central Africa for many years. Terry holds a Ph.D. from University College London and has published extensively on conservation and livelihood issues.

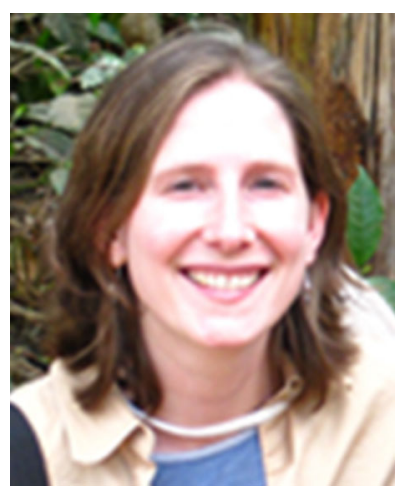

Anna Herforth Anna Herforth is a consultant specializing in the links between nutrition, agriculture and the environment. She consults for the World Bank, the UN Food and Agriculture Organization (FAO), and USAID's SPRI NG Project, among others. She has worked with universities, nonprofit organizations, and the CGIAR on food and nutrition in Africa, South Asia, and Latin America. She holds a Ph.D. from Cornell University in International Nutrition, an M.S. in Food Policy from Tufts Friedman School, and a B.S. in Plant Science from Cornell University. She is a founding member of the Agriculture-Nutrition Community of Practice. 